\title{
Fotografia socjologiczna - w kierunku reportażu dialogicznego
}

\author{
Tomasz Marcysiak \\ Wyższa Szkoła Bankowa w Toruniu
}

DOI: https://doi.org/10.18778/1733-8069.17.4.03

Słowa kluczowe: reportaż dialogiczny, fotografia, fotoreportaż, socjologia wizualna, fotografia dokumentalistyczna, wyobraźnia wizualna

\begin{abstract}
Abstrakt: Niemal 10-letnia współpraca z fotografem, który towarzyszy mi w badaniach terenowych, skłania do podzielenia się refleksją i uwagami metodologicznymi wynikającymi z doświadczenia budowania relacji pomiędzy badaczem, informatorem (informatorami) a fotografem. Doświadczenie to nazwałbym, za Piotrem Sztompką, procesem kształtowania się socjologicznej wyobraźni wizualnej. W ogólnym rozumieniu reportaż dialogiczny polega na doświadczaniu świata innych oraz na nauce odkrywania drugiego człowieka takim, jakim on sam widzi siebie w otaczającej go rzeczywistości. $\mathrm{W}$ artykule omawiam kwestie dialogu w badaniach wizualnych, zasady dobrej praktyki fotografii socjologicznej oraz ideę reportażu dialogicznego, ilustrując fotografiami z własnych badań terenowych prowadzonych w ramach takich projektów jak: „Tożsamość społeczności postmigracyjnej na przykładzie Kosznajderii”, „Życie codzienne mieszkańców gminy Cekcyn w Borach Tucholskich”, „Wpływ badań archeologicznych na integrację społeczności lokalnych w ramach projektu 1000 lat Górnych Łużyc” oraz „Szkice biograficzne druhów Ochotniczych Straży Pożarnych w gminie Golub-Dobrzyń”. Autorem wszystkich fotografii jest bydgoski artysta fotografik Dariusz Bareya.
\end{abstract}

Tomasz Marcysiak, socjolog, adiunkt w Katedrze Nauk Społecznych w Wyższej Szkole Bankowej w Toruniu. Autor publikacji z zakresu socjologii obszarów wiejskich, w tym Ochotniczych Straży Pożarnych i Gospodarstw Opiekuńczych. W zakresie zainteresowań społeczno-etnograficznych badacz Kosznajderii. W terenowej pracy badawczej współpracuje z fotografem Dariuszem Bareyą. Autor takich publikacji jak: WODA NAPRZÓD! Szkice z wywiadów autobiograficznych druhów Ochotniczych Straży Pożarnych z gminy wiejskiej Golub-Dobrzyń (Wydawnictwo Adam Marszałek,
Toruń 2019); T. Marcysiak, Kosznajderia - przerwana tożsamość [w:] A. Brzezińska, A. Szczepaniak-Koll, A. Szymoszyn, red., 300 lat Bambrów w Poznaniu. Wkład małych wspólnot migracyjnych $w$ dziedzictwo kulturowe Polski (Posnania, Instytut Archeologii i Etnologii PAN, Poznań 2019, s. 88-114).
Adres kontaktowy:
Wyższa Szkoła Bankowa w Toruniu
ul. Młodzieżowa 31a, 87-100 Toruń
e-mail: tomasz.marcysiak@wsb.bydgoszcz.pl 


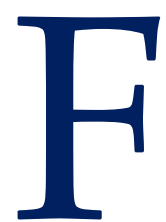

otografia socjologiczna to, zdaniem Piotra Sztompki, „penetracja za pomocą technik fotograficznych przestrzeni międzyludzkiej ujawniającej się w życiu codziennym" (Sztompka 2012: 28). Zdjęcia są tym lepsze (dodaje Sztompka), im mają większą moc ekspresyjną i perswazyjną, czyli cechują się szczególnym walorem estetycznym lub artystycznym (Sztompka 2012). Nie jest to $w$ fotografii socjologicznej jednak najważniejsze, gdyż w socjologii patrzymy nie tyle na zdjęcia, ale poprzez zdjęcia, bezpośrednio na świat społeczny. Jeśli tak, to czy można zastosować podział zdjęć socjologicznych na autentyczne i nieautentyczne, lub inaczej: subiektywne i obiektywne? Odpowiedź nie jest oczywista. Fotografia już ze swej natury jest wytworem subiektywnym. Technicznie rzecz ujmując, na jej efekt końcowy składają się trzy podstawowe parametry: przesłona, czas naświetlania i czułość matrycy. Ale aparat sam zdjęć nie robi, tak jak nawet najlepsze garnki nie ugotują potrawy. Niezbędny jest dobry fotograf, tak jak i znający się na swoim rzemiośle kulinarnym dobry kucharz. Niemal wszystko w fotografii zależy od kontekstu, nie od jakości wykonanego zdjęcia, choć akurat w tej kwestii wybrałem drogę fotografii cechującej się wysokim poziomem artystycznym. Jak zauważa Yaron Meron, fotografia jest formą wizualizacji i nawet najbardziej realistyczne zdjęcie zawsze będzie odbiciem fragmentu rzeczywistości (Meron 2019: 75). Współcześnie fotograf dzięki nowoczesnej technologii i możliwości cyfrowej obróbki zdjęć może sprawić, że każda jego fotografia będzie wyglądać jak autentyczna, choć w rzeczywistości będzie sztuczna i nieprawdziwa. Stąd też w mojej definicji autentyczna fotografia to ta, która może być punktem wyjścia do dyskusji równie angażującej socjologów, jak i krytyków fotografii, a za jej wykonaniem, obróbką i upublicznieniem muszą się kryć etyczne intencje badacza i fotografa. I oczywiście to, co w au- tentycznej fotografii jest najważniejsze, czyli: czy fotografia „mówi” prawdę? Francuski filozof Roland Barthes w swojej książce poświęconej fenomenowi fotografii opowiada pewną anegdotę o amerykańskim społeczeństwie, gdzie dochodzi do wniosku, że w dzisiejszych czasach (lata 70. XX wieku; przyp. T.M.) obrazy są żywsze od ludzi, wystarczy bowiem rozejrzeć się po gościach w kawiarni i zobaczyć, jacy są ponurzy. Żyjemy, zdaniem Barthesa, według uogólnionego repertuaru wizerunkowego, gdzie niemal wszystko przekształcone jest w obrazy (Barthes 1999: 118). Wnioskuję, że zdaniem tego teoretyka fotografii ilustracje zastępują ludziom ich prawdziwe życie lub co najmniej fałszywie pokazują „prawdziwe życie innych". Stąd w moim przekonaniu autentyczna fotografia to taka, która tego życia nie zniekształca i nie redukuje do kilkudziesięciu zdjęć kolorowanego magazynu czytanego u fryzjera lub w poczekalni do stomatologa, co już 40 lat temu zauważył autor eseju Camera Lucida (zob. Barthes 1999: 119).

Stosowany przez Darka Bareyę techniczny zabieg tworzenia czarno-białej fotografii już jest co prawda procesem zniekształcającym obraz, ale nie zniekształcającym rzeczywistości, że wspomnieć tu można takich klasyków czarno-białej fotografii jak: Jacob Riis, Lewis Hine, Robert i Helen Lynd, Dorothea Lang, Douglas Harper, Robert Frank, Bill Owens i wielu innych. Fotografia socjologiczna w mojej praktyce badawczej jest więc procesem twórczym, rozwojowym i edukacyjnym, podczas którego fotograf uczy się socjologii, a socjolog fotografii, wspólnie pogłębiając swoje kompetencje określane jako wyobraźnia wizualna (za Sztompka 2012: 37).

Fotografie są wszędzie, to podstawowy produkt naszej wyobraźni wykorzystywany w designie, re- 
klamie, sztuce, reportażu oraz w pracy naukowej. Jak zauważa Howard S. Becker, „trudno wyobrazić sobie obecnie biologię, fizykę czy astronomię bez dowodów w postaci zdjęć" (Becker 2012: 766). Także wprowadzając fotografię w obszar socjologii, używa się jej do badań interakcji, analizy emocji czy pozyskiwania informacji podczas wywiadów (Dempsey, Tucker 1994; Bang i in. 2016; Serafinelli 2017). Wykorzystanie obrazu w badaniach społecznych jest dziś nie tylko modne w środowisku akademickim, ale i konieczne. Sprzyja temu rozwój technologii cyfrowej i rosnąca popularność upowszechniania wyników badań drogą internetową. Jednym z entuzjastów wprowadzających fotografię jako metodę jakościową w obszar badań socjologicznych i etnograficznych jest Terenc Heng, który ponad dwie dekady fotografował uliczne rytuały i wydarzenia związane z chińskimi praktykami religijnymi w Singapurze (zob. Heng 2016; 2020). Heng przekonuje, że włączenie fotografii do repertuaru badawczego pozwala, po pierwsze, na ugruntowanie wykorzystania materiałów wizualnych $\mathrm{w}$ badaniach społecznych, a po drugie, na przełamanie archetypowego formatu artykułu w czasopismach nauk społecznych, które zazwyczaj ograniczają nie tylko ustaloną liczbą słów, ale i liczbą ilustracji. W jego opinii eseje wizualne dają ogromne możliwości połączenia tekstu i fotografii w taki sposób, by prezentowane wyniki badań terenowych dostarczały danych, których sam tekst nie jest wstanie osiągnąć (Heng 2019: 617). Autor Of Gods, Gifts and Ghosts, Terenc Heng, nie wyjaśnia, czy w swojej pracy badawczej wchodzi w dialog z fotografowanymi ludźmi, czy też zachowuje dystans, przyjmując postawę obserwatora ${ }^{1}$. Trudno oczywiście nawiązać kontakt z kimś, kto akurat jest w rytualnym transie,

\footnotetext{
${ }^{1}$ Moje pytanie w tej kwestii skierowane bezpośrednio do Terenca Henga jak do tej pory pozostaje bez odpowiedzi.
}

ale mimo wszystko nie jest bez znaczenia, czy ktoś jest, czy też nie jest w danym momencie świadomy, że fotografuje się go w trakcie praktyk religijnych, nawet jeśli mają one miejsce poza świątynią, na ulicy, w przestrzeni, w którą każdy z przechodniów może po prostu wejść.

Kiedy jedna osoba łączy rolę badacza i fotografa, można zrobić portret, sfotografować ludzi lub miejsca, zachowując kontekst obserwacji, ale nie może spojrzeć na siebie jako uczestnika sytuacji. Gdy w badaniu terenowym fotografią zajmuje się ktoś inny niż badacz, spektrum obserwacji poszerza się o uchwycenie relacji pomiędzy badaczem a uczestnikami sytuacji (respondentami, informatorami iinnymi aktorami społecznymi). Uczestniczący w badaniu fotograf może więc nie skupiać się na wątku rozmowy, ale dokumentować rozmowę i zachodzącą interakcję pomiędzy badaczem a respondentem lub grupą i po prostu uważniej patrzeć wokół siebie. Przestrzeń, w której nasz system wzrokowy może wykryć obecność bodźców, jest ograniczona naturalnym polem widzenia człowieka. Pole obserwacji fotografa jest więc szersze niż badacza nieposługującego się w trakcie badań aparatem fotograficznym, a sam badacz może skupić się na przykład na rozmowie. $\mathrm{W}$ efekcie materiał wizualny pochodzący z badań terenowych może stać się dla badacza swego rodzaju „kotwicą pamięci”, szczególnie w sytuacji, kiedy respondent nie wyraża zgody ani na sfotografowanie siebie, ani na nagrywanie rozmowy, a nie ma też warunków na sporządzanie na bieżąco notatek.

Takie sytuacje zdarzały mi się co prawda rzadko, ale tak jak w przypadku badań nad pracą osób obierających w swoich domach na wsi cebulę, gdzie intencją było stworzenie eseju wizualnego, pojawiła się luka $\mathrm{w}$ postaci braku fotografii najważniejszego aktora: 
obieracza cebuli (fig. B). W kolejnej jednak wsi udaje się przekonać inną osobę do portretu, tylko dlatego, że do rozmowy włączyłem wcześniejsze fotografie, z prośbą o zastanowienie się: „,czego tu brakuje?”. Fotografie przedstawiały więc zgromadzone w zagrodzie skrzynki z cebulą ułożone jedna na drugiej oraz badacza prowadzącego rozmowę (fig. A, C). Osoba, która oglądała te fotografie, sama więc stwierdziła, że przecież brak najważniejszego: człowieka pracującego przy obieraniu cebuli i to właśnie przekonało ją do zgody na zrobienie jej portretu podczas pracy (fig. D). Wizualny esej zaczął się więc wypełniać spójnym materiałem: cebula, otoczenie, człowiek. Efekt końcowy (uzyskanie zgody na fotografię) można było osiągnąć tylko na drodze dialogu, który, jak wykazałem wyżej, poprzez włączenie fotografii, rozwinął się w kierunku porozumienia, konsensusu i zgody na dalsze fotografie. Jest to, uważam, niezbędne, jeśli chce się uchwycić nie tylko kontekst sytuacji, ale i ujawnić to, co zazwyczaj jest niewidoczne, jednocześnie przyjmując postawę szacunku wobec badanych społeczności. Celem artykułu jest zatem przedstawienie tego, w jaki sposób podejmuję próbę kształtowania wyobraźni wizualnej w oparciu o podstawowe zasady reportażu dialogicznego i jakie efekty można tą drogą osiągnąć.
Figura A

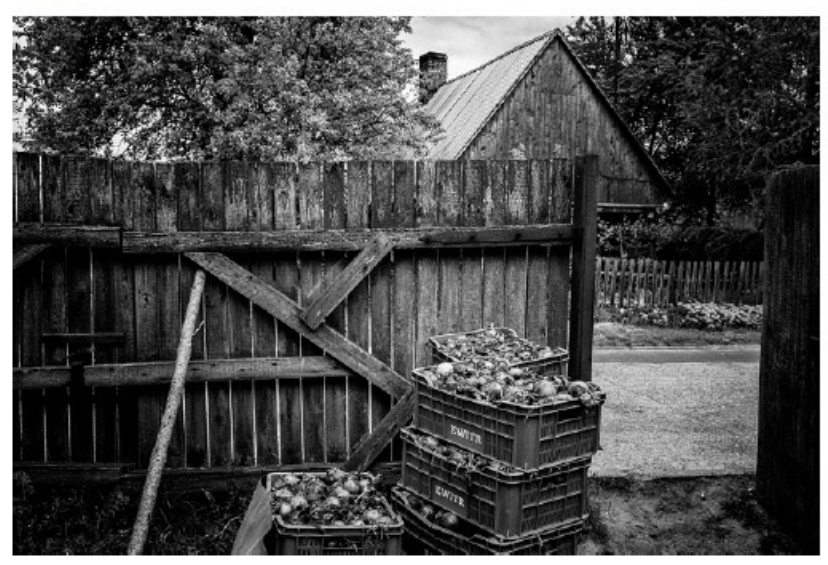

Figura C

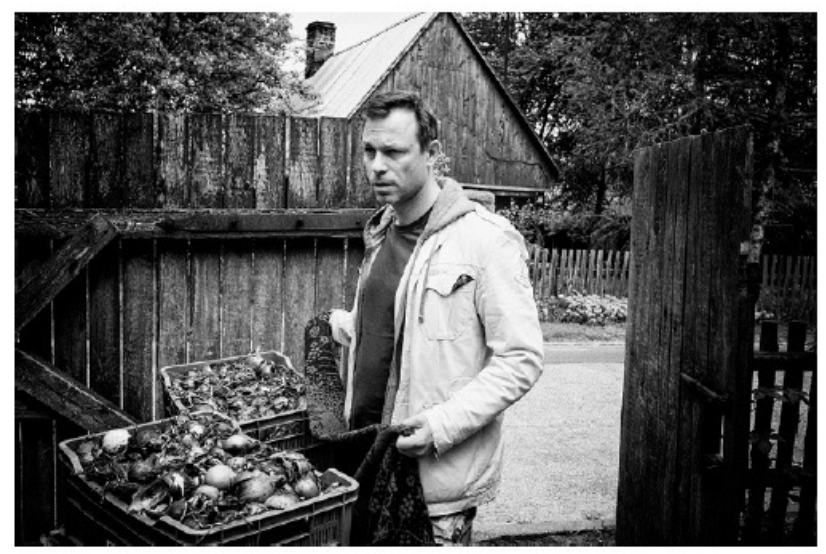

Figura B

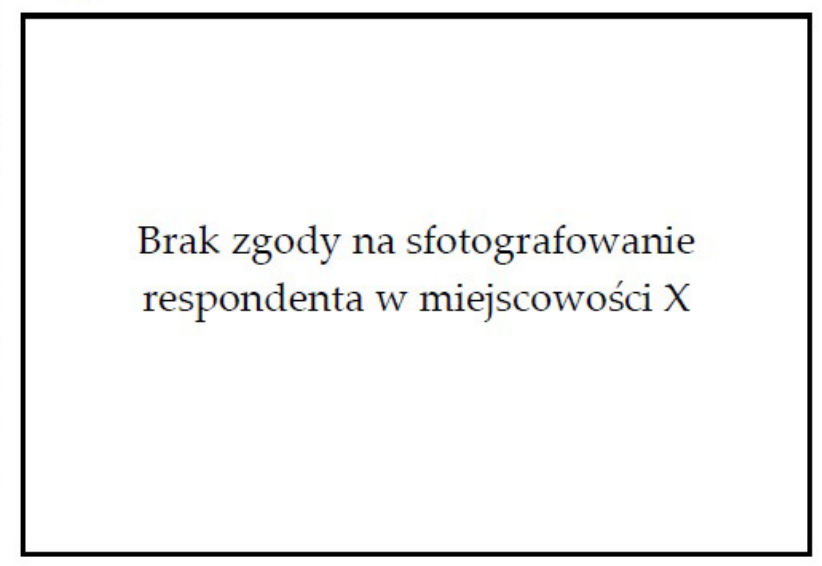

Figura D

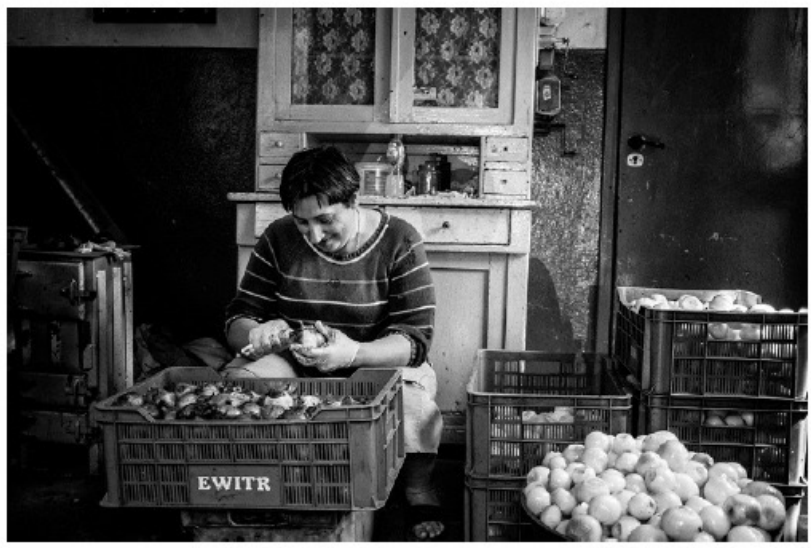

Fot. Dariusz Bareya 2015 


\section{Dialog $w$ badaniach wizualnych}

Zdarza się, że podczas wywiadu posiłkuję się wcześniej wykonanymi fotografiami, co kieruje uwage informatora na fotografie, niemal całkowicie odrywając jego uwage i od fotografa, i od badacza. Taka metoda ma swoje liczne zalety, do których należy przede wszystkim łatwość wywołania reakcji badanych. Jak zauważa Piotr Sztompka, „sytuacja wspólnego oglądania i komentowania zdjęć jest dla badanych bardziej naturalna niż odpowiadanie na zadawane przez ankietera wyłącznie werbalne pytania" (Sztompka 2005: 68). Socjolożka Tiffany Farey i fotografka Liz Orton twierdzą, że obrazy (o ile towarzyszy im wspólnie podzielany kod kulturowy definiowanych znaczeń dla obrazów) mogą posłużyć nie tylko do krótkiej wymiany opinii, ale pogłębionej relacji za pomocą dialogu. Dialog natomiast może przybierać bardzo różne formy. Interesującym przykładem jest dialog wizualny oparty jedynie na komunikacji za pomocą obrazów (fotografii). Farey i Orton przez niemal 10 lat przesyłały sobie zdjęcia za pośrednictwem poczty elektronicznej. Pierwsze zdjęcie było wiadomością, na którą należało odpowiedzieć tylko innym zdjęciem. $W$ ten sposób wymieniły między sobą ponad 260 fotografii zawierających sceny z ich życia rodzinnego, podróży, a także mówiące o ich smutku lub odczuwanym właśnie szczęściu. I choć przypomina to korespondencyjną grę w szachy, podczas której gracze (jeszcze z czasów poprzedzających pocztę elektroniczną) wysyłają sobie opisy ruchu figur na szachownicy, to w przeciwieństwie do królewskiej gry ten wizualny dialog nie był oparty o żadne zasady, poza jedną - wiadomością jest wyłącznie obraz. Autorki tego eksperymentu o początkach ich pomysłu piszą tak: „Kiedy zaczynałyśmy, nie miałyśmy żadnego konkretnego planu. Byłyśmy raczej ciekawe idei fotografii jako formy dialogu i chciałyśmy po prostu przekonać się, jak rozwinie się nasza wizualna rozmowa" (Fairey, Orton 2019: 299). Projekt ten pokazał między innymi to, czym jest dialog prowadzony przy pomocy obrazu i udowodnił, że podobnie jak przy dialogu werbalnym i tu moga pojawić się nieporozumienia wynikające $z$ odmiennego sposobu interpretacji obrazu. Fotografia ujawniła więc nie tylko swój potencjał, ale i liczne ograniczenia. Potencjałem jest szybka i szeroka możliwość transmisji obrazu przez różnorakie media (mobilność), ograniczeniem natomiast są emocje, jakie może on wywoływać, a które zależą już od indywidualnych doświadczeń odbiorcy obrazu (interpretacja). Autorki proponują więc pochylić się nad ideą fotografii dialogicznej, skoncentrowanej wokół spotkań, wymiany myśli, ale i negocjacji własnych poglądów, co w ich przekonaniu ujawnia szerszy kontekst fotografii, której treść może podlegać różnym interpretacjom, unikając w ten sposób zafałszowania informacji, jakie niesie ze sobą obraz pozbawiony komentarza. Uważają, że kompromis jest możliwy do osiągnięcia tylko poprzez dialog, który definiują, za fizykiem teoretycznym Davidem Bohmem, jako „proces, który w swej istocie polega na [wzajemnym - przyp. T.M.] uczeniu się" (Fairey, Orton 2019: 300).

W badaniach terenowych zarówno badacz, jak i fotograf przyjmują rolę obserwatorów, z których każdy zbiera dane w odmienny sposób, jeden poprzez rozmowę (wywiad), drugi poprzez fotografowanie. Należy jednak przy tym zwrócić uwagę, że każdy obserwator może mieć (i na pewno ma) wpływ na to, co obserwuje. W koncepcji dialogu Bohma obserwacja wpływa na emocje także obserwowanego, dlatego wpływ ten jest wzajemny (Bohm 2003: 69). O ile jednak w każdym z projektów badawczych, 
w których uczestniczyliśmy wspólnie (badacz i fotograf), przyjmujemy postawy obserwatora wolnego od uprzedzeń i niewchodzącego w głębszą dyskusję z rozmówcami², by zminimalizować wpływ badaczy na ich dotychczasowe sposoby definiowania rzeczywistości społecznej, o tyle już wracając do respondentów po jakimś czasie, dyskutowaliśmy na temat zrobionych wcześniej fotografii, możliwości ich wykorzystania czy nawet interpretacji zarejestrowanego obrazu. Treści pochodzące z wywiadu biograficznego czy narracyjnego (metod, jakie najczęściej wykorzystuję w pracy terenowej) nie podlegają już takiej reinterpretacji jak fotografie. $W$ tym więc sensie nasz dialog jest sposobem na budowanie „wspólnych znaczeń”, a te z kolei tworzą kulturę (Bohm 2003: 23). Zdaniem Bohma takie podejście (nadawanie wspólnych znaczeń) jest potrzebne współczesnemu społeczeństwu jak cement, który je spaja. Co prawda, jak dodaje Bohm, obecne społeczeństwa mają $\mathrm{w}$ sobie taki cement, ale jest on bardzo złej jakości, co w konsekwencji powoduje, że wspólnoty rozpadają się, tak jak ściany domów połączone kiepską zaprawą (Bohm 2003: 23). „Nasz” reportaż dialogiczny jest więc procesem otwartym, co oznacza, że kolejne cele eksploracyjne wyłaniają się w toku spotkań i rozmów face to face. W moim przekonaniu wartość tak definiowanego reportażu dialogicznego polega na doświadczaniu świata innych, dlatego proces ten nie może podlegać nadmiernym regułom kontroli. Choć niewątpliwie należy przyjąć pewien zestaw dobrych praktyk prowadzenia społecznych badań terenowych z udziałem fotografa.

Jako badacze przyjmujemy więc odpowiedzialność za udostępniane wyniki obserwacji wraz z uzgod-

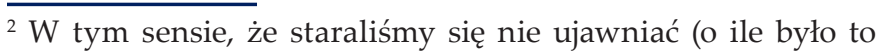
możliwe) swoich przekonań, poglądów czy tym bardziej światopoglądu.
}

nionym na drodze dialogu $\mathrm{z}$ fotografowanymi ludźmi, interpretacji ich zdjęć i znaczeń, jakie im przypisują. Pojedyncze zdjęcie, jak mawia amerykańska fotografka dokumentalna Susan Meiselas, jest jak wyjęcie z pudełka jednego puzzla, nie spoglądając na ilustrację z okładki. Ten kawałek bez reszty układanki nie ma sensu, tak jak każda fotografia, która jest częścią czegoś, co jeszcze nie zostało ujawnione (za Fairey, Orton 2019: 304). Podobnie jak zresztą uważa Howard S. Becker, twierdząc, że nie można używać jednego zdjęcia jako substytutu szerszego uniwersum (Becker 2012: 771). Moi rozmówcy tworzą więc ramę większej całości, w której z wolna dopasowują się obrazy, nadając im sens i umiejscawiając w konkretnym kontekście społecznym. Podejmowany przeze mnie wysiłek zrozumienia życia społecznego poprzez reportaż dialogiczny dostarcza co prawda interesujących materiałów złożonych ze słów i obrazów, ale nie rozwiązuje kwestii ukrytych za pogłębioną analizą socjologiczną ani nie pokazuje społeczeństwa w sposób prosty i jednoznaczny. Jest to jedynie zbiór obrazów i tekstów, które jak złączone ze sobą puzzle dopiero co odkrywają fragmenty większej całości.

Dlatego też od czasu do czasu wracam do zdjęć pochodzących z moich badawczych projektów, po pierwsze, aby ćwiczyć wrażliwość wizualną, który to trening (jak wyjaśnia Piotr Sztompka) poszerza wyobraźnię socjologiczną i pozwala odkryć coś więcej, gdyż „wniknięcie w treść zdjęć, nawet pojedynczych, może nasunąć nam nowe kategorie socjologiczne, pojęcia niezbędne do uchwycenia widocznych tam, a ignorowanych dotąd przez socjologię niuansów życia społecznego" (Sztompka 2005: 71). Po drugie, zwyczajnie po to, by podziwiać fotografie. Jak mówiła Elsa Dorfman w filmie poświęconym jej fotograficznej twórczości: „Bar- 
dzo niegrzecznie jest zachwycać się nim [zrobionym przez siebie zdjęciem - przyp. T.M.], ale jak już zrobię zdjęcie i widzę je w ten sposób, jestem od nich w pewien sposób oddzielona. O swoim dziecku nie wypada mówić, że jest urocze albo fantastyczne. Ale o swojej pracy mogę tak powiedzieć. Czuję dumę i niedowierzanie, ale nie jestem fałszywie skromna"3. Patrzę więc na te zdjęcia i mówię sobie - są świetne, choć wybór fotografa mogącego sprostać takiemu wyzwaniu nie był sprawą całkiem prostą.

W grudniu 2014 roku w jednej z lokalnych gazet w Bydgoszczy ukazał się reportaż opisujący świąteczną akcję charytatywną "Bigos dla bezdomnych", która z czasem przyjęła się pod nazwą „Ciepło serca w słoiku”. Jako ilustrację wykorzystano czarno-białe fotografie podpisane pseudonimem Dariusz Bareya. Autor fotografował nie tylko wolontariuszy niosących w dłoniach słoiki z ciepłym bigosem, w tym inicjatorkę akcji Sandrę Pawłowską, ale także beneficjentów, czyli bydgoskich bezdomnych, samotnych i opuszczonych. Fotografie Barei już wtedy odbiegały od typowego fotoreportażu prasowego, skupiając uwagę widza na szczegółach: dłoniach z plastikowymi naczyniami i kubkami wypełnionymi jedzeniem i ciepłą herbatą oraz na portretach ludzi, często robionych z niewielkiej odległości. Autentyzm sytuacji poszerzał się wraz z perspektywą prowizorycznej noclegowni, postaci wykluczonych i bezdomnych niczym na fotografiach Jacoba Riisa sprzed ponad 100 lat. Ponadto Bareya osiągnął coś znacznie więcej niż tylko "dobre zdjęcie" ilustrujące akcję charytatywną. Nadał bezdomnym nową, spokojną i przyjazną twarz (zdjęcie 1). Mężczyzna w kapeluszu trzyma-

${ }^{3}$ The B-Side: Elsa Dorfman's Portrait Photography (2016) reż. Errol Morris. jący plastykową łyżkę i niemal cały swój dobytek w jednej reklamówce z lekkim uśmiechem zdaje się mówić: „nie ma się czego bać, ja jestem przecież George". W pewnym jednak sensie to tylko złudzenie. Fotografia nie mówi nam, jak faktycznie wygląda codzienne życie mężczyzny, z jakimi problemami musi się mierzyć, a nawet co w tej chwili myślał.

Na pierwszym naszym spotkaniu Dariusz Bareya ujawnił mi trochę informacji ze swojego warsztatu fotograficznego, co bez wahania przekonało mnie o tym, że to może być owocna współpraca: "Zanim zrobię zdjęcie, niemal zawsze staram się najpierw porozmawiać, wyjaśnić, jeśli to konieczne, po co to robię. Nie ma tu sekretu czy recepty na dobrą fotografię jakiejś sytuacji, czy portret. Najważniejsza jest rozmowa z ludźmi, w końcu podejście $\mathrm{z}$ aparatem czasem na odległość kilkudziesięciu centymetrów jest czymś zdecydowanie przekraczającym granicę, jak to się teraz często mówi - strefę komfortu. To fotografia relacyjna, łącząca na chwilę fotografa i fotografowanego, który nie jest modelem, obiektem, przedmiotem, jest po prostu człowiekiem i dopiero potem, jak już widz spojrzy na powstałą $\mathrm{w}$ ten sposób fotografię, sam może powiedzieć, ocenić, czy to tylko zdjęcie, czy może już artystyczne dzieło" (Dariusz Bareya). To podejście przekonało mnie, by podjąć próbę realizacji wspólnego projektu, w którym udałoby się połączyć fotografię z jakościowymi badaniami terenowymi, mając na początku tylko taki cel: jeśli czegoś nie zapiszę, fotografia wypełni tę lukę. Skoro więc sam fotograf uważa swoją pracę za fotografię relacyjną opartą na rozmowie, to trzeba było teraz tę wiedzę usystematyzować i włączyć w repertuar badań terenowych, do czego najlepiej przystaje w mojej ocenie reportaż dialogiczny. 
Zdjęcie 1. Mówią do mnie George

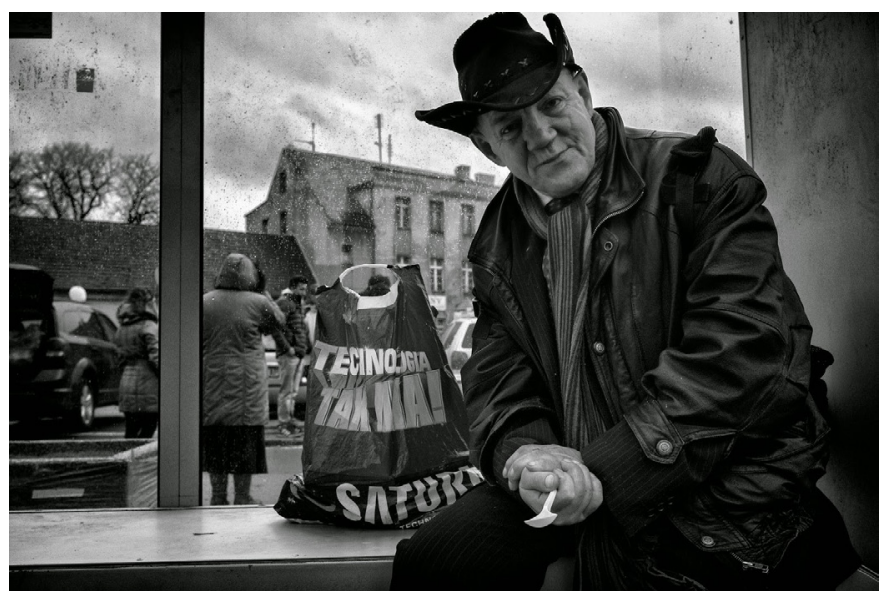

Fot. Dariusz Bareya 2010

\section{Reportaż dialogiczny}

Wszelkiego typu obrazy są postrzegane przez socjologów wizualnych przede wszystkim jako narzędzie opisu społeczeństwa (Sztompka 2012: 26). Natomiast w przypadku badań terenowych, które w większości przypadków przynoszą dane jakościowe, a więc obserwacje, których nie można w prosty sposób sprowadzić do liczb, kluczową kwestią jest całościowa perspektywa (Babbie 2007: 309). Naturalne otoczenie, w jakim badacz prowadzi obserwacje, pozwala na analizę określonych procesów społecznych w określonym czasie i miejscu, dając tym samym możliwość dostrzeżenia szerszego kontekstu. Dlatego socjolog czy etnograf w terenie musi zastosować się do ogólnie przyjętych i zaakceptowanych metod czy procedur badawczych, zwłaszcza jeśli poszerza repertuar technik i narzędzi o metody wizualne. Nie ma gotowych wskazówek na dobre zdjęcie socjologiczne, ale istnieje wiele tekstów, które próbują tworzyć pewne podpowiedzi metodologiczne. Charles Suchar pokazuje na przykład, w jaki sposób można włączyć fotografie dokumentalistyczne do badań opartych o metodę teorii ugruntowanej (Suchar 1997). Terence Heng wy- jaśnia, jakie są najważniejsze zasady tworzenia eseju wizualnego w naukach społecznych, jako sposobu komunikowania odkryć czynionych przez socjologów wizualnych (Heng 2019). Sylvain Baruchel, Iris Epstein, Patricia McKeever i Bonnie Stevens opisali, w jaki sposób wykorzystywać fotografie w wywiadach z dziećmi chorymi na raka i co niezwykle istotne w tego typu badaniach społecznych, także jak za pomocą zdjęć budować z chorymi dziećmi zaufanie i dobre relacje (Baruchel i in. 2006). Howard S. Becker tłumaczy natomiast, jak socjologowie wizualni powinni rozwijać swój warsztat fotograficzny (fotoreportaż, fotografię dokumentalistyczną), by ich zdjęcia odróżniały się od tych, które może dziś zrobić „każdy", tak by były nie tylko przedmiotem uwagi krytyków fotografii, ale pomocnym narzędziem w lepszym zrozumieniu życia społecznego (Becker 1995). A Tamara Kay koncentruje swoją uwagę na etycznych i społecznych konsekwencjach publikowania fotografii, która może pełnić nie tylko funkcję informująca opinię publiczną, ale także funkcję wspierającą ruchy społeczne czy polityczne (Kay 2011).

Wachlarz tych wskazówek i podpowiedzi jest oczywiście znacznie szerszy, ale nadal trudno znaleźć odpowiedź na pytanie: czym jest „dobre” zdjęcie socjologiczne, ponieważ wiele z fotografii zakwalifikowanych później do ilustracji badanego zjawiska powstaje wcale nie $\mathrm{w}$ ramach precyzyjnie wyznaczonych reguł, ale przypadkiem lub co najmniej w zależności od okoliczności i okazji. Czasem najlepsze ujęcia powstają na samym początku wywiadu, czasem na sam koniec, kiedy respondent zgadza się na przykład na portret, innym razem najlepsze zdjęcie powstaje $\mathrm{w}$ trakcie rozwiniętej już rozmowy, gdy rozmówca przestaje zwracać uwagę na fotografa. W prezentowanym przeze mnie podejściu fotografia wzmacnia narrację respondentów i nierzadko udaje się uchwycić emocje towarzyszące wspomnieniom, 
chwile zawieszenia rozmowy, czasem nawet niezręczne milczenie. Bywa więc, że z kilkugodzinnego wywiadu wybieramy zaledwie jedną fotografię, która najbardziej oddaje klimat rozmowy, otoczenia lub najbliżej oddaje sens obserwowanej sytuacji. Żadne spotkanie nie kończy się okrzykiem „cięcie, mamy to", gdyż, w przeciwieństwie do takich fotografów jak John G. Morris, naszą misją nie jest „zdobycie zdjęcia” (get the picture, za Morris 2007). Choć bez watpienia ulegam takiej właśnie pokusie stwierdzenia „mamy to", mimo że nigdy nie było to celem moich badań. Wciąż więc nie mam pewności, czy to jest już ta „dobra" fotografia socjologiczna. Badając naturę fotografii, Roland Barthes doszedł do przekonania, że w dobrej fotografii musi być coś szczególnego, choć przy okazji nieokreślonego, coś co przenika obserwatora, wręcz go "kłuje”. Jak pisze Barthes w Camera Lucida: „Od czasu do czasu (ale niestety zbyt rzadko) przyciąga mnie «szczegół». Czuję, że sama jego obecność zmienia sposób, w jaki patrzę na nowe zdjęcie, które w moich oczach ma wyższą wartość. Ten «szczegół» to punctum" (Barthes 1999: 42 [tłum. T.M.]).

W fotografii socjologicznej nie skupiam się jednak na uzyskaniu efektu punctum, czy - jak dziś byśmy mogli nawet powiedzieć - wow punctum. Świadomie więc $\mathrm{w}$ trakcie prowadzonych badań rezygnuję z setek zdjęć, by później wybrać kilka, ale skupiam się na narracji, chcąc niemal wejść w opowieść i zobaczyć historię oczami mojego narratora. Wykonanie fotografii pozostawiam artyście, który ma nie tylko dobrą intuicję i wyczucie, ale włącza się w proces badawczy, w rolę przypisaną do dialogu z badaczem i dialog z narratorem. Innymi słowy, nie wchodzimy sobie $\mathrm{w}$ trakcie badań w drogę, a nierzadko też wzajemnie sobie ustępujemy.

Podejście to (skoncentrowanie uwagi na narracji) wpisuje się $\mathrm{w}$ uprawiany przez wielu fotografów reportaż dialogiczny. Fotograf nie jest tu widzem oglądającym świat, który stanowi dla niego jedynie scenę, ale stara się zredukować lub nawet zlikwidować dystans i barierę, które oddzielają fotografa od świata. Innymi słowy, spotkanie fotografa z drugim człowiekiem nie jest krótkie i ulotne jak w przypadku fotografii do dokumentów tożsamości. Jak wyjaśnia André Rouillé, „fotograf i osoby, które fotografuje, są wspólnie zaangażowane w realizację tego projektu, w którym wykonanie zdjęcia jest jedynie krótką chwilą, a niekoniecznie zwieńczeniem całego procesu" (Rouillé 2007: 210). Reportaż dialogiczny uprawiany jest przez wielu fotografów, którzy, jak zauważa Rouillé, „zrezygnowali z uganiania się za sensacją" (Rouillé 2007: 209). Najbardziej reprezentatywni przedstawiciele tego gatunku fotografii w Europie Zachodniej to: Nick Waplington, Luc Choquer, Olivier Pasquier, Marc Pataut, Patrick Bard czy Patrick Zachmann. Wszyscy ci fotografowie zdobyli się na to, by tworzony przez nich zapis fotograficzny opierał się na dialogu, wymianie i bliskości.

Ten gatunek reportażu wymaga czasu, ale nie po to, by uchwycić „ten krótki moment”, ale po to, by najpierw nawiązać dialog. W jednym $\mathrm{z}$ wywiadów Tomasz Gudzowaty w rozmowie z publicystą Andrzejem F. Rozhinem tak wspominał ostatnie zdjęcie, które zrobił w klasztorze Shaolin: „Nasz pomysł był taki: zróbmy historię o umiejętnościach tych mnichów. Jeden umie chodzić po murze, drugi ręką rozbije wiadro z woda, inny staje na głowie, ktoś umie rozbić stos cegieł. Zdjęcie mnicha biegnącego po murze zrobiłem w ostatnim dniu. $W$ ostatniej godzinie naszej pracy trafiłem na moment, kiedy on pokazywał tę sprawność młodym adeptom”" ${ }^{\prime \prime}$ Ktoś mógłby powiedzieć, że niczym się nie różni takie zdjęcie od

\footnotetext{
4 https://www.swiatobrazu.pl/100-najbardziej-zaskakujacychzdjec-swiata-tomasz-gudzowaty-mnich-z-shaolin-30001.html [dostęp 11.04.2013].
} 
„strzału” z ogromnego obiektywu, skoro i tak nie miał okazji nawiązać z mnichem żadnych relacji. Otóż już sam fakt, że mógł podejść tak blisko do mnicha z klasztoru Shaolin było wielkim osiągnięciem. Biorąc jednak pod uwagę stopień komercjalizacji kung-fu i samego klasztoru, wokół którego powstało już tyle szkół walki, że zaciera się (lub już zatarła) granica pomiędzy autentycznością a sztucznymi obszarami zakulisowymi, trudno dziś stwierdzić, że fotograf ma możliwość obserwowania nieskrępowanych zachowań wspólnoty mnichów. Wydaje się więc, że w klasztorze Shaolin nic nie jest pozostawione przypadkowi, a fotograf, tak jak każdy inny turysta, postępuje zgodnie z instrukcją, która objaśnia jak, kiedy i na co patrzeć (zob. Urry 2007: 22-35). A mimo to, przyglądając się zdjęciom mnichów Tomasza Gudzowatego, widz ma wrażenie „nieskalanego naturalnego piękna", jakim jest codzienny rytuał treningu mistrzów klasztoru Shaolin i nikt nie może powiedzieć: „widziałem to już gdzie indziej”. Nie jest to jednak reportaż dialogiczny, ponieważ nie wykracza poza uchwycone pozory, nie wyraża życiowych sytuacji i nie wychodzi poza sferę tego, co widzialne, jest monologiem. W fotografii dialogicznej nie chodzi o „fotografowanie przedmiotów lub ludzi, ale o fotografowanie stanów przedmiotów wraz z ludźmi" (Rouillé 2007: 213). Dodałbym jednak, że to także fotografowanie ludzi w ich codziennych, czasem rutynowych praktykach, także tych za kulisami.

Waplington do swojego trwającego 4 lata projektu pt. Living Room zaangażował członków dwóch rodzin robotniczych dotkniętych kryzysem, fotografując ich podczas codziennych czynności. Fotografie Waplingtona przekraczają pewną granicę intymności, ujawniając ludzi takimi, jakimi są na co dzień w bezpiecznej dla nich przestrzeni własnego domu. Nikt poza dziećmi nie pozuje do zdjęć. Wszyscy wydają się być na tyle zrelaksowani, że nie przeszkadza im to, jak są ubrani, jaki nieład panuje w pokoju, czy nawet to, czy akurat kłócą się, jedzą lody lub oglądają telewizję. Powstający w ten sposób portet rodzinny Waplington uzyskuje między innymi dzięki temu, że członkowie rodziny niemal całkowicie zapominają o jego obecności i aparacie fotograficznym (Stanley 1996: 97). John Berger tak napisał o projekcie Waplingtona: „To, co jest niezwykłe w tych fotografiach, to szczególny sposób, w jaki upubliczniają intymność; coś, na co my, którzy nie znamy osobiście obu sfotografowanych rodzin, możemy patrzeć bez poczucia wtargnięcia do czyjegoś domu [tłum. T.M.]”' Z Z kolei Luc Choquer koniec XX wieku chciał zatrzymać w portretach francuskiego społeczeństwa. Rezultaty jego pracy zostały zaprezentowane nie tylko podczas wielu wystaw, ale także w fotograficznych monografiach: Portrait de Français i Planète France. Istotą fotografii Choquera było poszukiwanie decydującego momentu, niczym u Bressona, $\mathrm{z}$ tą jednak różnica, że nie pojawiał się w owym decydującym momencie $\mathrm{z}$ aparatem, tylko godzinami na ten moment cierpliwie czekał. Jak mówi o sobie: „Żadna z moich fotografii nie jest inscenizowana i nigdy nie retuszuję kadru [tłum. T.M.]”' . Nie podróżował jednak sam. Swoimi poglądami o ludzkich losach, namiętnościach i charakterach dzielił się z towarzyszącym mu w reporterskiej podróży przyjacielem i jednocześnie psychologiem Bernardem Pelossem, którego z kolei zadanie polegało na namówieniu fotografowanych ludzi przed sesją zdjęciową do opowiedzenia o sobie. Jak wspomina Luc Choquer w jednym zwywiadów przeprowadzonych przy okazji otwarcia wystawy jego prac w muzeum Montparnasse w Paryżu: „Za każdym razem, gdy wychodziłem z sesji, zrobione zdjęcia były niemal anegdota, ponieważ kiedy odwiedzałem ludzi w ich domach, czułem, że

\footnotetext{
${ }^{5} \mathrm{https} / / /$ placartphoto.com/book/2480/living_room-nick_waplington [dostęp 26.10.2021].

${ }^{6}$ https://www.ouest-france.fr/bretagne/lorient-56100/lorient-luc-choquer-ou-la-photographie-humaniste-6307349 [dostęp 26.10.2021].
} 
to nie tylko sesja fotograficzna, ale także towarzyskie spotkanie. Z czasem odkryłem, że w mojej pracy brakuje jednego wymiaru, który mógłby przekazać istotę tych spotkań: rozmowy. Zastanawiałem się, jak zorganizować połączenie fotografii i rozmowy. Stąd pomysł, żeby wcześniej sfilmować wywiady z osobami, które zamierzałem sfotografować. Powierzyłem to zadanie mojemu przyjacielowi Bernardowi Pelosse [tłum. T.M.]". 7 W tym samym wywiadzie Bernard Pelosse, uzupełniając wypowiedź fotografa, stwierdza, że dzięki temu połączeniu (fotografii i rozmowy) „nauczyliśmy się odkrywać drugiego człowieka tak, jak on widział siebie w świecie, w jego rzeczywistości [tłum. T.M.]" ${ }^{\prime \prime}$.

Dzięki tej współpracy album Portraits de Français oprócz 120 kolorowych portretów kobiet, dzieci, nowożeńców, nastolatków na biwaku, mężczyzn relaksujących się pracą w ogródku czy pracowników biurowych zawiera także obszerne wypowiedzi bohaterów zdjęć, ujawniające ich lęki przed życiem czy niepokoje związane z przemijaniem i starością. Aby zachęcić ludzi do rozmów, Bernard Pelosse wykorzystywał pozornie proste narzędzie badawcze znane jako test osobowości na podstawie kwestionariusza Prousta9. Tym samym sesje fotograficzne przeradzały się w spotkania z ludźmi, którzy chętniej zwierzali się ze swoich wątpliwości i pragnień. Każdą już potem sesję zajęciową poprzedzał kwestionariusz składający się z 54 pytań, co odpowiadającym na nie ludziom zajmowało czasem tylko godzinę, a czasem nawet pół dnia ${ }^{10}$.

\footnotetext{
7 https://www.afrik.com/luc-choquer-presente-portraits-de-francais [dostęp 29.10.2021].

8 https://www.afrik.com/luc-choquer-presente-portraits-de-francais [dostęp 29.10.2021].

${ }^{9}$ https://actuphoto.com/13096-portraits-de-francais-luc-choquer.html [dostęp 29.10.2021].

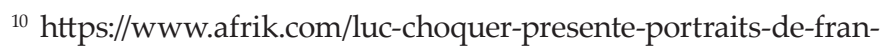
cais [dostęp 29.10.2021].
}

Jednak nie zawsze łatwo jest zdobyć zaufanie tych, których chce się ujawnić światu. Szczególnie trudno sfotografować ludzi pozostających na skraju wykluczenia lub żyjących od lat na marginesie życia społecznego. Dla przykładu Olivier Pasquier, który fotografował przez kilka lat bezdomnych w schronisku we Francji, zdobywał ich zaufanie w długim i delikatnym procesie akceptacji. Dzięki tej bliskości był w stanie wykonać portrety, w których przywracał godność osobom, przełamując dzięki swoim fotografiom uprzedzenia wobec bezdomnych (Gagnon 2008: 22). Z tej koncepcji inspiracje czerpał natomiast Marc Pataut, który fotografował osadzonych w aresztach więźniów. Kluczowy dla fotografii okazał się czas przebywania wśród osadzonych. Początkowo artysta oczekiwał, że będzie mógł uwiecznić na fotografii braterstwo więźniów, jednak z dnia na dzień przekonywał się o tym, że prowadzą raczej indywidualistyczny tryb życia i bliższe prawdy o nich były ich samotne portrety w celach (Gagnon 2008: 23). Najbardziej chyba niezwykłe było doświadczenie Patricka Barda, który w 1983 roku, biorąc pewnego dnia do ręki aparat fotograficzny, nie sądził, że będzie poprzez cykliczne fotografie opowiadał transpłciowe przemiany swojego siostrzeńca, tworząc tym samym poruszający fotoreportaż o poszukiwaniu tożsamości ${ }^{11}$. Bard przez ponad 35 lat dokumentuje, jak Jean-Pierre najpierw staje się Jeanne, potem ponownie mężczyzną, by ostatecznie przemienić się w kobietę Jeanne-Victoire.

W swojej pracy dziennikarze czy fotografowie prasowi bywają bardzo wymagający wobec ludzi, których fotografuja, po czym, kiedy już „zdobędą zdjęcie”, ich współpraca się kończy, a zdjęcie trafia do opinii publicznej za pomocą prasy, Internetu czy telewizji.

\footnotetext{
11 https://new.in-24.com/entertainment/News/15115.html [dostęp 29.10.2021].
} 
Wymaga od nich tego specyfika pracy fotoreporterskiej, a nawet krótkie polecenie zleceniodawcy, którym wielokrotnie był John M. Morris, dający wysyłanym w teren fotografom kilka wskazówek, wśród których najważniejszą była „musicie zrobić zdjęcie” (Morris 2007: 21). Patrick Zachmann wyjaśnia, że zawsze czuł się trochę sfrustrowany taką sytuacją. Postanowił dzielić się z osobami, które fotografuje, czymś więcej niż tylko chwilą na spotkanie. Mówi więc tak: „Nie dawaj ludziom pieniędzy, ale możesz oddać ludziom coś innego i to na wiele sposobów. Ja na przykład oddaję ludziom zdjęcia, które im zrobiłem, czasem je też podpisuję, a nierzadko wracam, aby sfotografować ich ponownie. To właśnie wzmacnia relację między nami (...). Zrozumiałem również, że możesz odwdzięczyć się ludziom, po prostu będąc z nimi, słuchając ich i zwracając na nich uwagę. Bardzo często osoby, które fotografowałem, czują się opuszczone lub zapomniane, więc są bardzo poruszone faktem, że spędzasz z nimi czas. Jeśli słuchasz ludzi, między tobą a tematem jest intymność, a zdjęcia, które robisz, będą lepsze [tłum. T.M.]"12.

Jak zauważa Rouillé, ten gatunek reportażu wymaga czasu, wzajemnego zaufania i pogłębionego dialogu i dopiero wówczas model staje się aktorem, partnerem i podmiotem, a fotografie są autentyczne (Rouillé 2007: 211). Reportaż dialogiczny jest zatem wyrażeniem życiowej sytuacji, a fotografia nie jest tylko odtwarzaniem tego, co widzialne, ale tego, co ukryte za wykluczeniem z życia politycznego czy społecznego. Nigdy jednak nie można tego dokonać wbrew ludziom, których się fotografuje, ale zawsze za ich zgodą i z ich pomoca, dlatego niezbędne jest przestrzeganie kilku podstawowych zasad i procedur składających się na ten „,nowy język fotograficzny” (za Rouillé 2007: 212).

\footnotetext{
12 https://www.canon.pl/pro/stories/patrick-zachmann-magnum-best-advice/ [dostęp 29.10.2021].
}

W omawianym przeze mnie podejściu fotograf nie jest $\mathrm{z}$ boku, ale także jest zaangażowany w dialog, choć w inny, niewerbalny sposób, ponieważ ostatecznie jest tym, który dokonuje poprzez fotografię syntezy narracji, miejsca i ekspresji. Od początku więc przystając na sugestię fotografa, usadawia się podczas wywiadu naprzeciw mojego rozmówcy. To dość nietypowa sytuacja, podczas której informator omawia na przykład wątki swojej biografii, kierując wzrok to przed siebie, na fotografa, to znów na badacza lub gdzieś w przestrzeń, jakby szukając potwierdzenia swojej historii u niewidzialnej publiczności. Dzięki takiemu zabiegowi udaje się uchwycić w trakcie trwającego czasem kilka godzin spotkania najważniejsze akcenty rozmowy i emocje, jakie towarzyszyły informatorowi dzielącemu się autobiografią. Taka sytuacja miała miejsce wielokrotnie, choć najdokładniej ilustrują to fotografie $\mathrm{z}$ rozmowy poświęconej relacji Polaków z Kosznajdrami (Niemcami) w okresie poprzedzającym wybuch II wojny światowej, potem w pierwszych latach okupacji i jej końca (zdjęcie 2, $3,4,5)$.

\section{Zdjęcie 2. Pan Franciszek z Ogorzelin (1. 93). Od urodzenia mieszkaniec wsi kosznajderskiej}

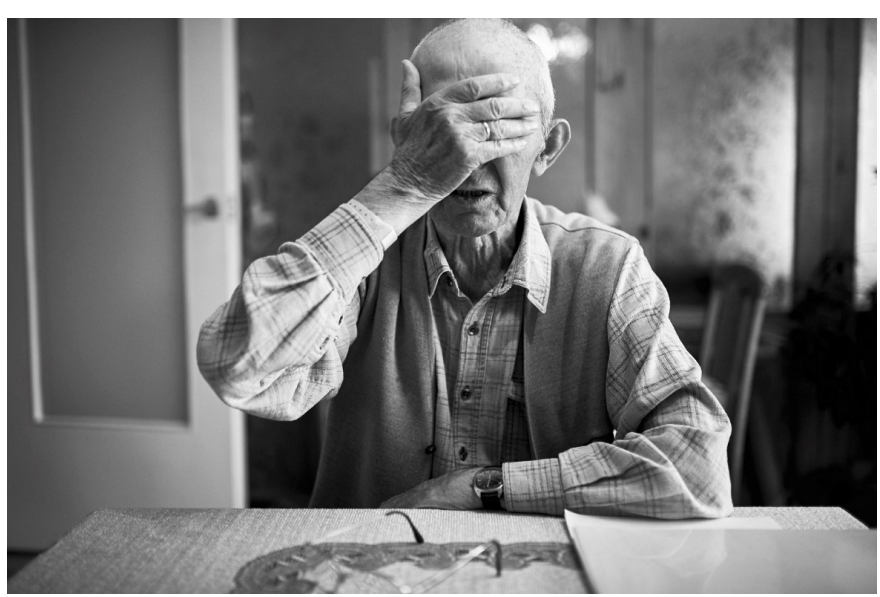

Fot. Dariusz Bareya 2018 
Zdjęcie 3, 4, 5. Pan Franciszek w trakcie wywiadu autobiograficznego - Ogorzeliny
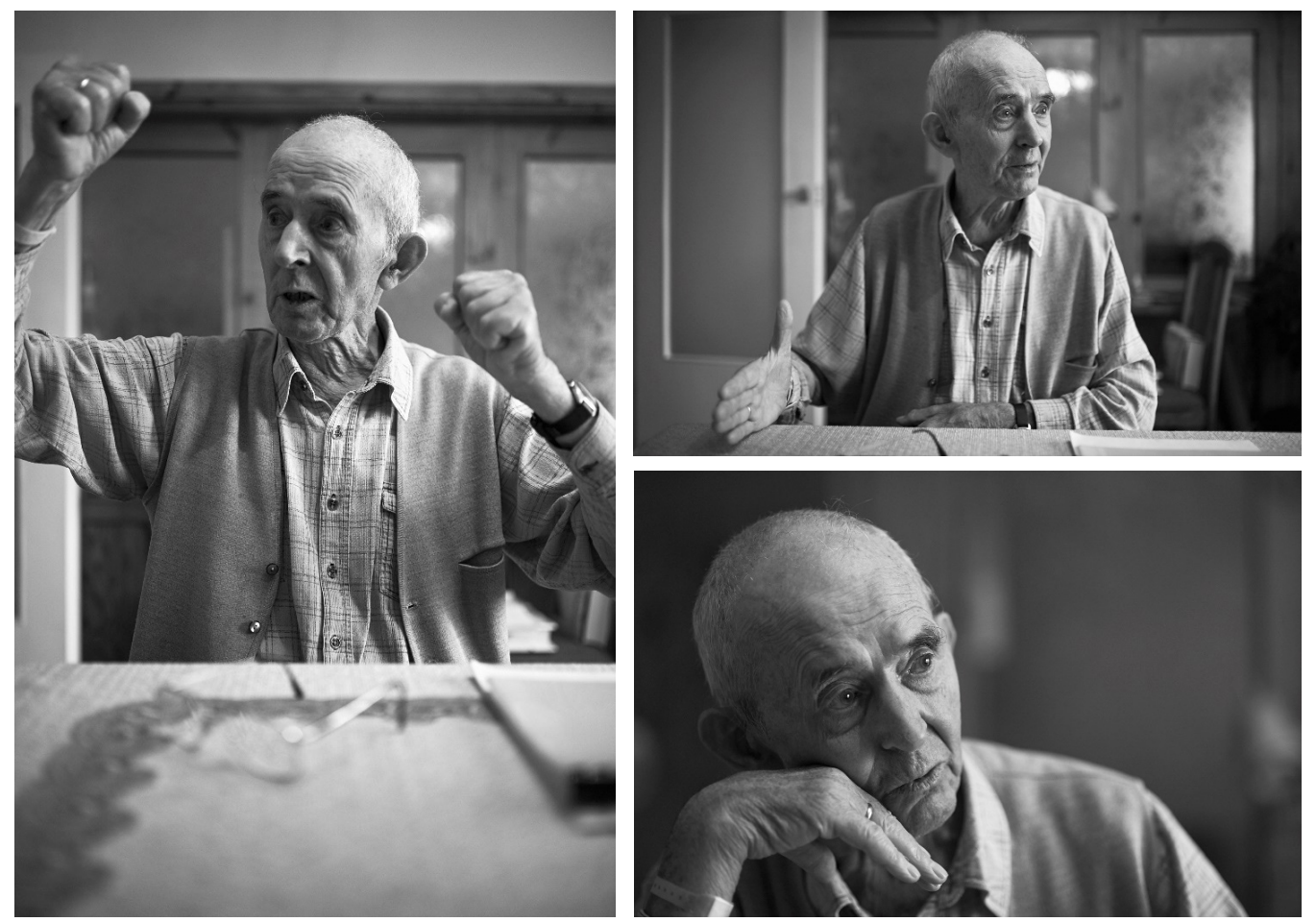

Fot: Dariusz Bareya 2018

Reportaż dialogiczny nie jest więc zbiegiem przypadków, gdzie w nieprzewidziany sposób można osiągnąć wymóg obiektywizmu i realizmu. Stąd też chcąc połączyć intencje artystyczne i estetyczne z etyką badań społecznych oraz właściwym celem, czyli uzyskaniem werbalnej wypowiedzi na interesujący badacza temat, decyduję się na przyjęcie kilku praktycznych dla reportażu dialogicznego zasad. Istnieje jednak pewne zagrożenie, polegające na tym, że badany będzie bardziej koncentrował się na aparacie fotograficznym niż na badaczu, co niewątpliwie zmniejsza spontaniczność i autentyczność wypowiedzi. Dlatego ważne jest poprowadzenie wywiadu z udziałem fotografa według podobnych standardów, jak przy wywiadzie socjologicznym, gdzie powodzenie zależy nie tylko od doboru respondenta, ale także od wytworzenia i utrzymania właściwej atmosfery (Rychliński 2001: 75).

\section{Zasady dobrej praktyki fotografii socjologicznej}

Pierwszą zasadą, którą kieruję się, łącząc socjologiczną obserwację z fotografia, jest zadbanie o to, by nie ingerować $\mathrm{w}$ najmniejszym stopniu $\mathrm{w}$ to, co ludzie robia, nie zakłócać ich codziennego rytmu i tego, co robia, bez względu na to, z jakiego powodu to robią (za Becker 1974: 18). Mam jednak świadomość, że obecność obserwatora, a tym bardziej dwóch, ma wpływ na to, że ludzie nie zachowują się tak, jak zawsze, ale przynajmniej tak, jak zazwyczaj. Czasem bywa tak, że obecność fotografa jest łatwiejsza do zaakceptowania, bo już sam aparat zawieszony na szyi pozwala potencjalnym rozmówcom zdefiniowanie obcego: „a, to fotograf, porobi zdjęcia i pójdzie"13. Innym razem jest wręcz odwrotnie, chętnie porozmawiam, ale absolut-

\footnotetext{
${ }^{13}$ Sparafrazowana wypowiedź jednego z moich respondentów.
} 
nie proszę nie robić żadnych zdjęć - „czy ten pan z aparatem może poczekać przed domem"114? Bywa więc, że moi rozmówcy i tak godzą się potem na jedno, dwa zdjęcia, ale zazwyczaj i to wystarczy. Zdecydowanie łatwiej jest namówić jednak artystów, ludzi, którzy cenią i rozumieją sztukę, naturalność i autentyczność. Przygotowując do druku pierwszą książkę, w której wykorzystałem fotografie pochodzące $\mathrm{z}$ badań terenowych w Cekcynie (Marcysiak 2015), wysłałem do wszystkich, których zdjęcia miały się pojawić w monografii, prośbę o zaakceptowanie. Natychmiast odezwał się jeden z respondentów, który zdecydowanie się sprzeciwił, ponieważ (choć zdjęcie mu się podobało) obawiał się oceny ze strony swojej przyszłej małżonki, a ślub był zaplanowany za kilka miesięcy. Odpisał mi więc, że „po ślubie, to możesz publikować, ale teraz poproszę o jakieś bardziej neutralne" i tak się stało ${ }^{15}$. W to miejsce wstawiłem więc fotografię lokalnego miłośnika zabytkowych motocykli, których w zasadzie nie kolekcjonuje, ale z pasją naprawia (zdjęcie 6, 7). Na planie fotografii dostrzegamy zabytkowe radio, które stanowi część kolekcji radioodbiorników wnuka pana Mieczysława, Tomasza. Rodzinna pasja majsterkowania w jednej przestrzeni, garażu, łączy pokolenia, mimo że rodzaj zainteresowań jest zgoła odmienny. W jednym pomieszczeniu wnuk naprawia zabytkowe radioodbiorniki, a jego dziadek motocykle. Niewielki garaż jest międzypokoleniowym miejscem spotkań, rodzinnych i tematycznych gawęd o naprawianiu „starych przedmiotów". W dodatku kolekcją radioodbiorników mogłoby się poszczycić niejedno muzeum, zwłaszcza że wszystkie (a było ich wówczas ponad 60) są sprawne i działają (zdjęcie 8).

\footnotetext{
${ }^{14}$ Sytuacja dotyczyła faktycznego zdarzenia, które miało miejsce podczas badań we wsiach dawnej Kosznajderii, kiedy to zaskoczeni naszą wizytą właściciele jednego z gospodarstw pozwolili, by tylko jeden $\mathrm{z}$ nas wszedł do domu. Następnym razem przyjęto nas obu.

${ }^{15}$ Nawet po kilku latach mój rozmówca sfotografowany wówczas podczas pracy w gospodarstwie nie wyraża zgody na publikowanie zdjęć.
}

Zdjęcie 6, 7. RetroGarage - Pan Mieczysław wśród swoich motocykli, wieś Zdroje
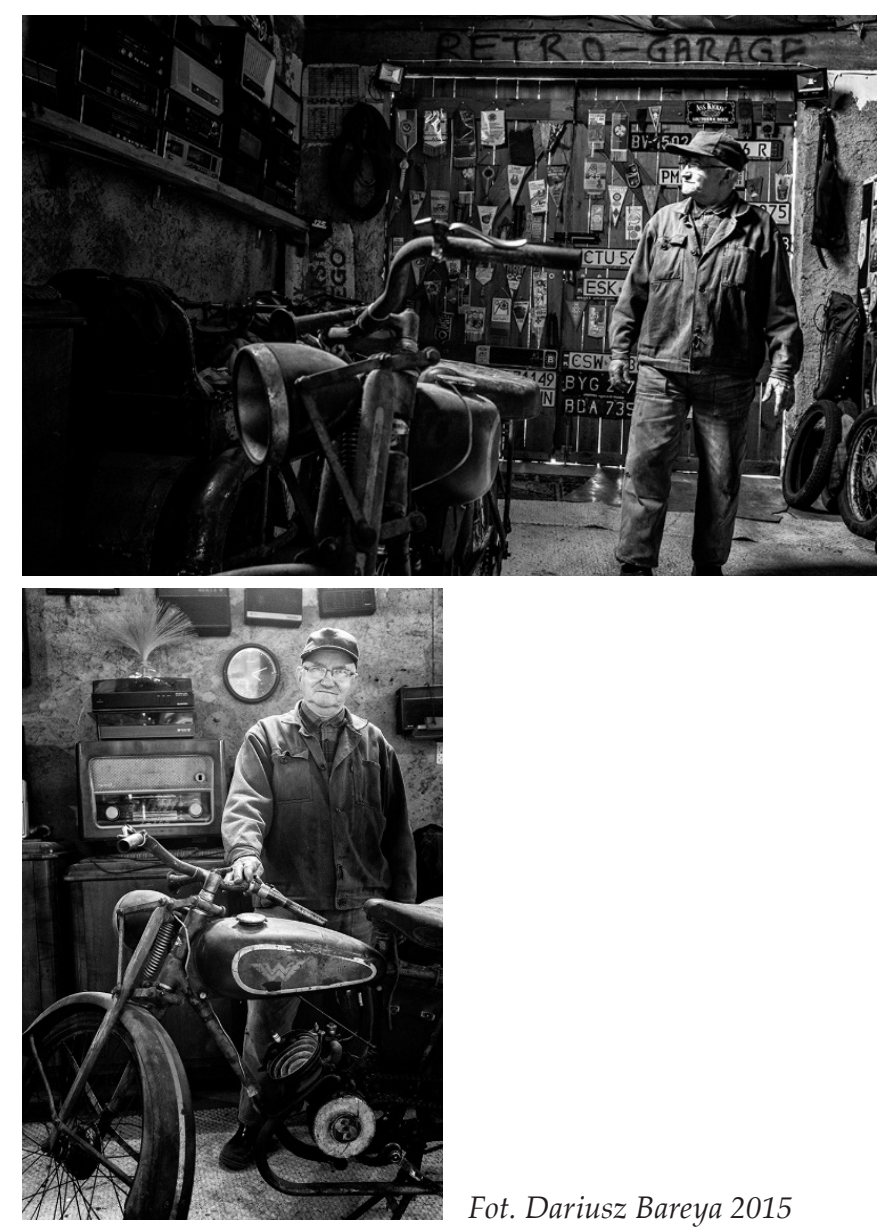

Fot. Dariusz Bareya 2015

Zdjęcie 8. Tomasz, wnuk pana Czesława. Wspólny warsztat naprawy zabytkowych radioodbiorników i motocykli

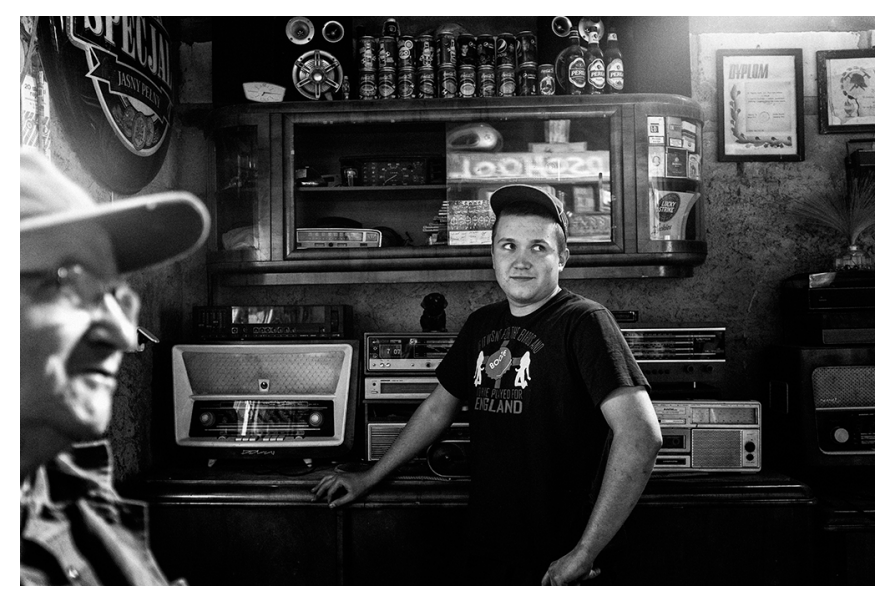

Fot. Dariusz Bareya 2015 
Druga zasada dotyczy etycznych intencji. Oczywiście i moim zmartwieniem jest, czy będę mógł taką fotografię upublicznić. Nawet jeśli jest małe prawdopodobieństwo, że bohater zdjęć znajdzie swoją fotografię w książce, artykule naukowym czy nawet na wystawie fotograficznej, a nie mam od niego zgody, to takiego zdjęcia nie upubliczniam, nawet jeśli już Howard S. Becker pisał, porównując pracę fotografa do praktyki lekarskiej: ,jeśli zaprzyjaźnisz się ze swoimi pacjentami, oni nie będą cię pozywać do sądu, nawet jeśli popełnisz błąd w sztuce lekarskiej" (Becker 1974: 19 [tłum. T.M.]). Rozwiązanie problemu zgody na publikację fotografii rozstrzygam więc, wzorując się na zaleceniach Marcusa Banksa, czyli badaniach opartych na współpracy, które rozumiane są jako praca wykonywana wspólnie z respondentami, a nie praca o nich (zdjęcie 9). Wprowadzając respondentów w proces badawczy, wyjaśniam na samym początku, że nie są tylko informatorami, ale że cenię ich kompe- tencje i umiejętności, które wzbogacają naszą wiedzę oraz przedstawiam cel i intencje badania (Rose 2010: 295-298). Innymi słowy, respondenci są moimi ekspertami, współtwórcami narracji, podobnie zresztą jak czyni się to na przykład w badaniach autoetnograficznych (Jones, Adams, Ellis 2015; Kafar, Kacperczyk 2020). Jeśli udaje się rozmowę utrzymać się w tonie szczerości i prostoty, a respondent nie odczuwa przy okazji presji czasu, zachęcam na koniec wywiadu do portretu, co bywa niekiedy rzeczą na prawdę trudną, jak w sytuacji, kiedy rozmówca prosi przy tym o pomoc w przygotowaniu się do zdjęcia. W relacji badaczrozmówca wyraźnie wówczas widać zmniejszenie się dystansu do poziomu przekroczenia pewnej granicy intymności, granicy bezpieczeństwa, gdzie badacz na chwilę staję się opiekunem godnym zaufania, co zilustrują trzy kolejne fotografie: wywiad, kulisy przygotowania do portretu i efekt końcowy - portret weterana wojennego (zdjęcie 9, 10, 11).

\section{Zdjęcie 9, 10, 11. Weteran II wojny światowej, żołnierz Armii Berlinga}
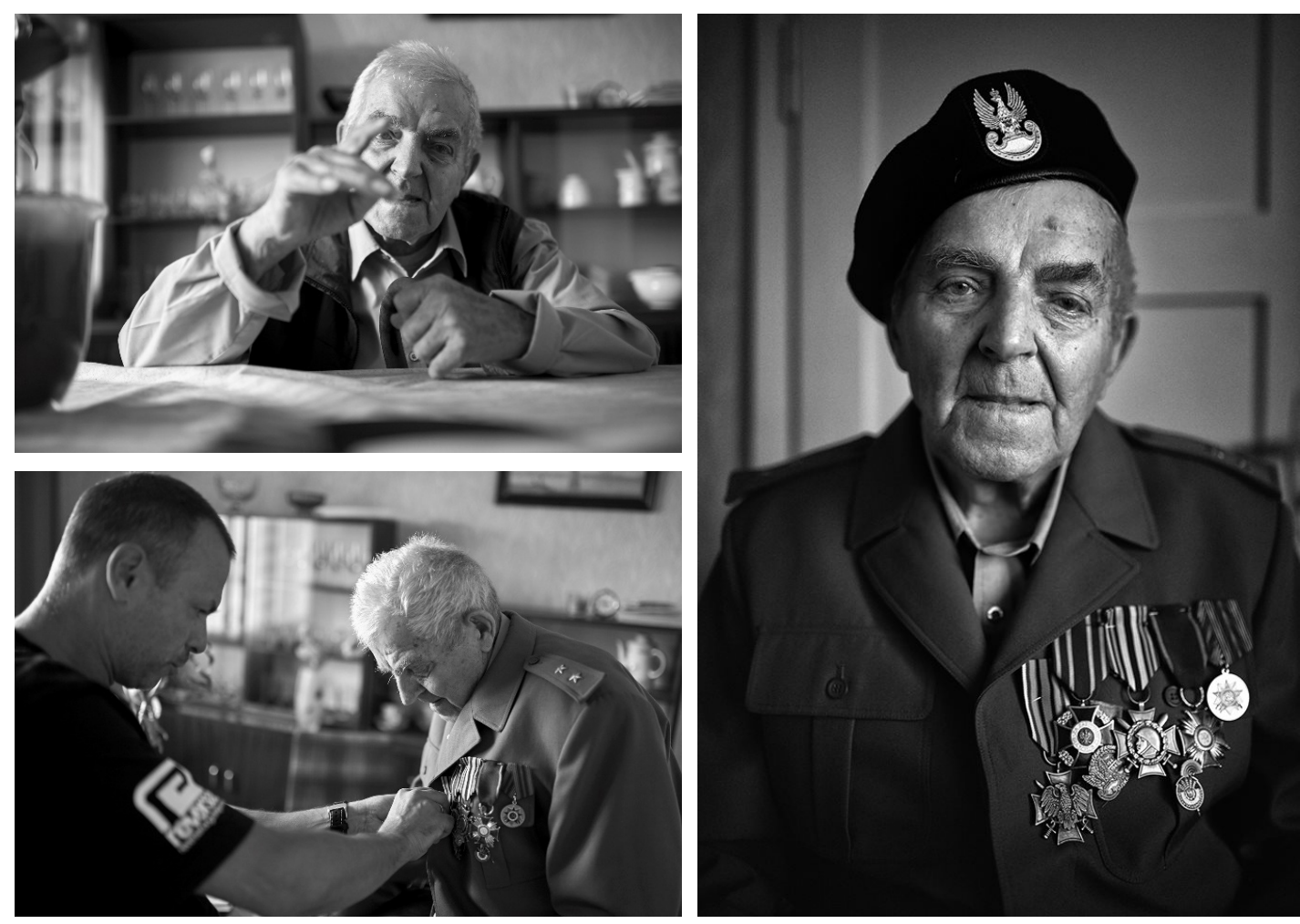

Fot. Dariusz Bareya 2017 
W powyższym kontekście (upublicznienia fotografii) szczególne doświadczenie niesie ze sobą dokumentowanie badań prowadzonych przez archeologów i antropologów. Ludzkie kości nie wyrażą zgody na publikację ich wizerunku i jakkolwiek makabrycznie czy groteskowo to brzmi, to $\mathrm{w}$ ich imieniu podejmują decyzję archeolodzy, nie fotograf. Jest to o tyle istotne, że współczesne badania archeologiczne wychodzą poza obszar odgrodzony taśmą wyznaczającą teren wykopalisk, ale wpisują się coraz częściej w ideę community archaeology czy public archaeology, czyli informowania o rezultatach badań archeologicznych i angażowania mieszkańców w prace wykopaliskowe. Skala oddziaływania prowadzonych badań archeologicznych na lokalną społeczność jest bardzo różna, ponieważ trudno jeszcze przełamać $\mathrm{w}$ polskim społeczeństwie postawy wobec pracy archeologów definiowanej jako: „problem, kłopot, utrudnienie" i tym podobne. I chociaż archeologia może stać się ważnym przyczynkiem do pogłębienia wiedzy o regionie, czynnikiem utrwalającym poczucie tożsamości czy dumy z miejsca urodzenia lub zamieszkania, to jednak bardzo łatwo stworzyć wokół odkrycia mit niezgodny z utrwalonym kontekstem kulturowym (zob. Marcysiak, Pretkiel, Raszkowska 2017). W jednym więc miejscu, jak w przypadku mieszkańców wsi Ostrowite (wieś dawnej Kosznajderii), istnieje ogromne zainteresowanie badaniami archeologicznymi prowadzonymi na terenie pobliskiego jeziora, bo, jak twierdzą mieszkańcy, „to część naszej chrześcijańskiej kultury", w innym - lokalna społeczność niemal w ogóle nie interesuje się ustaleniami archeologów, bo na przykład dotyczą wykopalisk sprzed „zaledwie” 100 lat, jak w przypadku Toporowa. Co nie zmienia faktu, że promując badania archeologiczne, nie zwalnia to archeologów, antropologów czy towarzyszących ich pracy fotografów z refleksji nad etyką ich badań (zdjęcie 12).

\section{Zdjęcie 12. Antropolodzy w trakcie oględzin szczątków z cmentarza dawnej osady} Prędocice (Toporów, niem. Tormersdorf), dziś zlokalizowanej w województwie dolnośląskim

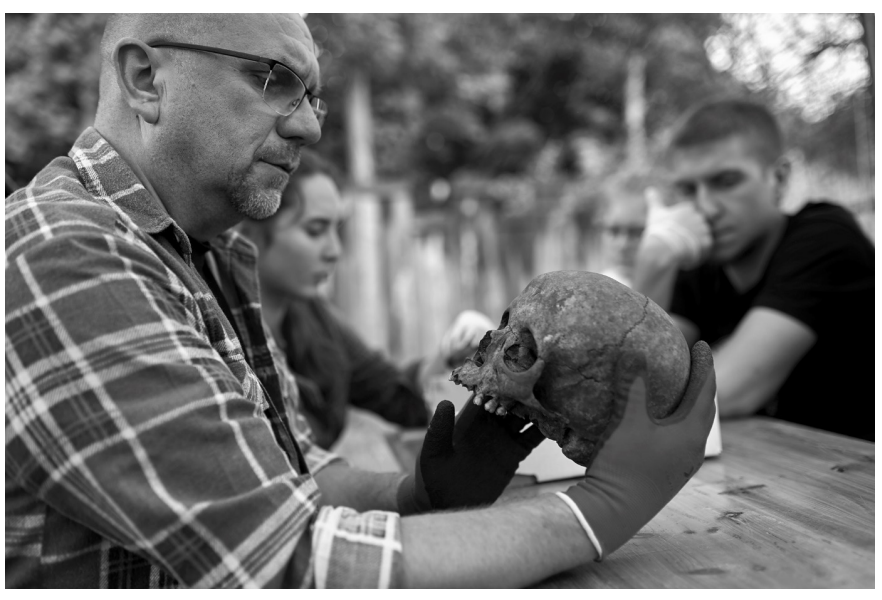

Fot. Dariusz Bareya 2018

Trzecia zasada dotyczy reguł uczestnictwa fotografa $w$ badaniu. Jeśli towarzyszący tobie $w$ badaniach fotograf jest dobrym dokumentalistą, który w dodatku specjalizuje się $\mathrm{w}$ fotografowaniu nieoczywistych obiektów i który rejestruje również to, co dzieje się za interesującym ciebie kadrem, to możesz być pewien, że po wywołaniu zdjęć znajdziesz fotografie, których się nie spodziewałeś (Jeffrey 2014: 311). Nie oznacza to, że moim celem jest dorównać Garry'emu Winograndowi, którego dorobek szacuje się na bagatela $5 \mathrm{mln}$ fotografii. Winogrand miał ponadto zwyczaj nie wywoływać wszystkich zdjęć od razu, czasem czekał nawet kilka lat, by nabrać do nich dystansu.

Liczbę zrobionych zdjęć podczas jednego wyjazdu badawczego pozostawiam fotografowi, który dopiero po kilku dniach i po ich obróbce wysyła mi od kilku do kilkunastu zdjęć do analizy czy oceny. Robi się niebezpiecznie, kiedy mam do wyboru zbyt dużo zdjęć, podobnie gdy jest ich za mało, zgodnie z zasa- 
dą przywoływaną między innymi przez Krzysztofa Olechnickiego, że „niedobór informacji jest, co prawda, niekorzystny, lecz jej nadmiar może być jeszcze gorszy" (Olechnicki 2003: 149). Posiadanie jednak bogatego archiwum fotografii pozwala na wyodrębnienie wielu kategorii, które jako drugorzędny materiał wizualny (w tym sensie, że nie był związany bezpośrednio z tematyką badań) może stanowić cenne źródło danych wizualnych faktów społecznych ilustrujących na przykład przenikanie się w wiejskiej przestrzeni sacrum i profanum (zdjęcie 13).

\section{Zdjęcie 13. Rzeźba frasobliwego Chrystusa}

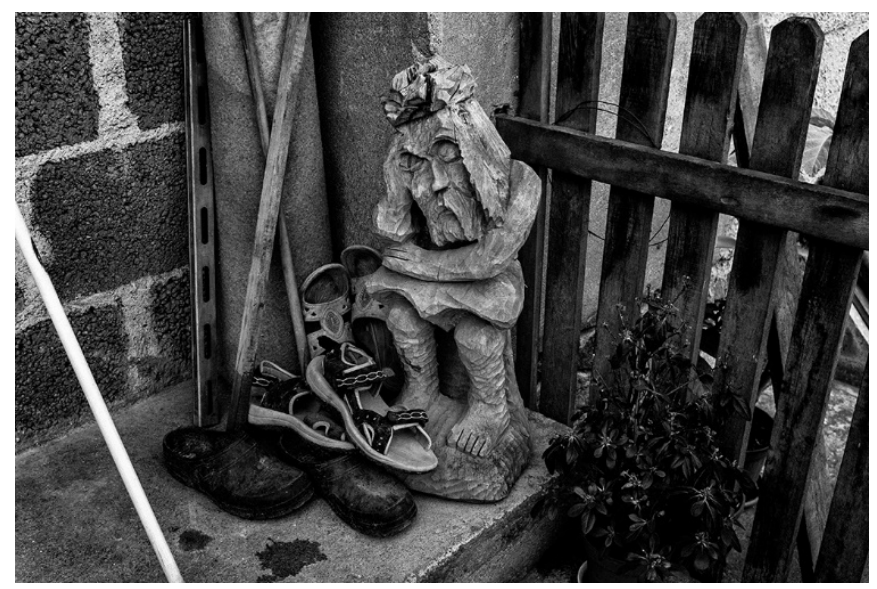

Fot. Dariusz Bareya 2015

Czwarta zasada to autentyczność. W badaniach terenowych fotograf koncentruje się na swojej pracy, a ja na swojej, jednak obaj mamy świadomość, że to, co zostanie zapisane (umownie mówiąc) na kliszy i w dyktafonie przetrwa nas, naszych rozmówców i wszystko, co nas w tym momencie otaczało. Nie można traktować więc fotografii jako „aktu nieinterwencji" w sytuacji, gdy sama obecność jest już interwencją. Jak wyjaśniał to Claude Lévi-Strauss, „odwiecznym problemem badacza jest to, że zmienia on obiekt badań przez samo obcowanie z nim. Pa- trząc na nasze zbiory (...) opowieści - czy mają one znaczenie i porządek jako takie, czy też ów porządek został narzucony przez antropologów, którzy je zebrali"? (Lévi-Strauss 2020: 29). W drodze na wywiad uzgadniamy dosłownie $\mathrm{w}$ kilku słowach nie co fotografować, a co jest tematem badań. Jeśli więc prowadzimy badania nad tożsamością społeczności postmigracyjnej $\mathrm{w}$ dawnej Kosznajderii, przedmiotem zainteresowania będzie układ sieci osadniczej, architektura zabudowań mieszkalnych i gospodarczych oraz wszelkie zachowane jeszcze relikty przeszłości, które mogą, ale nie muszą już mieć dla nowych pokoleń osadników żadnego znaczenia (Marcysiak 2019a), oraz najważniejsi, czyli ci, którzy podtrzymują pamięć zbiorową o wydarzeniach okresu okupacji i ostatnich niemieckich osadnikach $\mathrm{w}$ tym regionie. Jeśli jednak przedmiotem badań jest życie codzienne mieszkańców wybranej gminy (Marcysiak 2015), fotografujemy szkoły, klasy, podwórka, przystanki autobusowe, cmentarze, polne drogi i mobilne sklepy, jeśli zaś przedmiotem uwagi jest wolontariat pełniony w ramach ochotniczych straży pożarnych, na fotografiach znajdą się remizy, wozy strażackie i sceny z ćwiczeń, akcji strażacki, zawodów drużyn pożarniczych i oficjalnych uroczystości czy pokazu przedszkolnej drużyny pożarniczej (Marcysiak 2019b).

Trudno jednak całkowicie uznać, że nasza fotografia właśnie spełnia kryteria autentyczności, czyli zasady, której wierny był jeden z pierwszych fotografów pracujących w terenie - Peter Henry Emerson. Jego fotografie ludzi pracujących na polu i torfowiskach czy podczas zbioru trzciny z lat 1886-1887 charakteryzują się dobrze określoną głębią ostrości, gdzie to, co na pierwszym planie jest ostre, a im dalej, tym obraz staje się stopniowo rozmyty. Zabieg ten nie tylko przybliżał fotografię Emersona do sztuki, jak uważa John Szarkowski (2005: 24), ale czynił fotografię przybliżoną do tego, jak ludzkie oko widzi w rzeczywistości. Za- 
rzut może być zatem taki, że ludzkie oko widzi jednak w kolorach i przyjęcie konwencji czarno-białych zdjęć nie tylko nie jest prawdziwe, ale także podkreśla w celowy sposób dramaturgię i przybliża taką fotografię do sztuki (zdjęcie 14, 15, 16). Chociaż właśnie czarno-biała fotografia ukształtowała fotografię dokumentalistyczną, fotoreportaż i fotografię socjologiczną.

\section{Zdjęcie 14. Drewniana wieża do suszenia węży strażackich w Małej Cerekwicy}

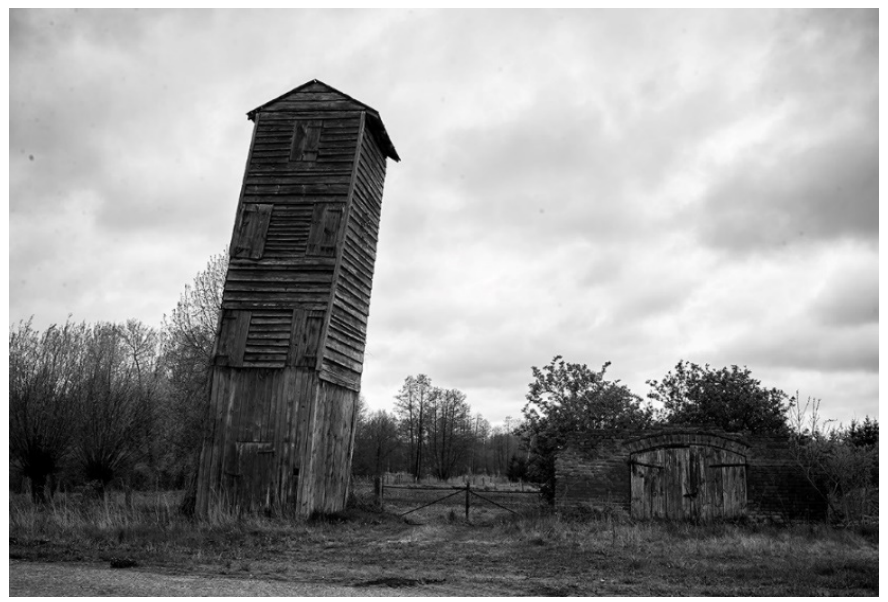

Fot. Dariusz Bareya 2018

\section{Zdjęcie 15. Pokaz przedszkolnej drużyny} pożarniczej z Nowogrodu (gmina Golub-Dobrzyń)

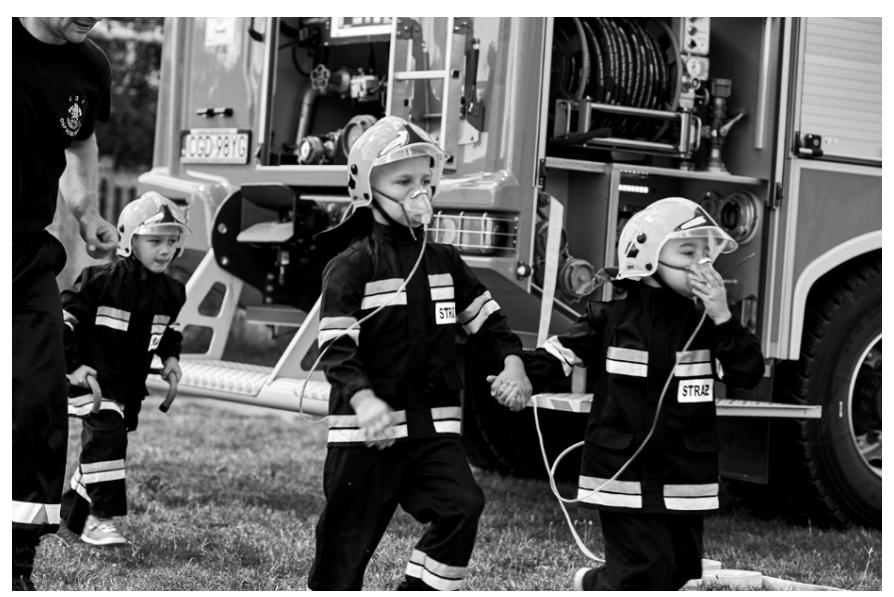

Fot. Dariusz Bareya 2019

\section{Zdjęcie 16. Rozgrzewka przed meczem - boisko piłki nożnej we wsi Ostrowite, koło Chojnic}

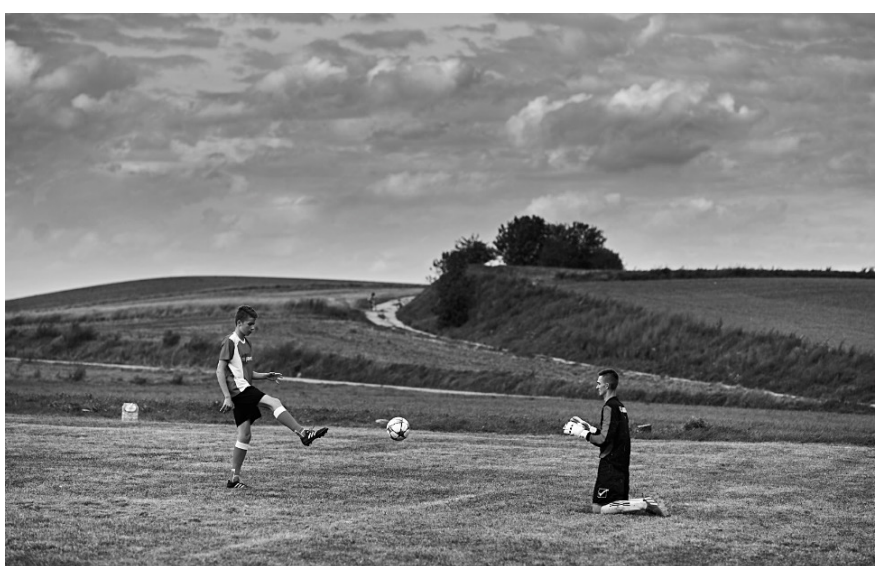

Fot. Dariusz Bareya 2019

Zdaję sobie sprawę, że współczesna fotografia, a raczej technika wykroczyła dalece poza proste odtworzenie tego, co naturalne, od tego, co zainscenizowane. A przecież intencją „naszej” fotografii wykorzystywanej $\mathrm{w}$ reportażu dialogicznym jest przekonanie widza o jej autentyczności. Dla przykładu, Iwona Stachowska, pisząc o współczesnej fotografii ludzkiego ciała, stwierdza, że ,jakkolwiek efekt końcowy zaskakuje swą autentycznością, to nie można zapomnieć, że stanowi on przykład świadomej ingerencji twórcy i został wywołany celowo, z jego inicjatywy" (Stachowska 2009: 9). Zdarza się, że respondenci czasem pozują do zdjęcia, chcąc niejako pomóc fotografowi w jak najlepszym ujęciu rejestrującym akurat wykonywane czynności, ale czyż nie "demonstrowali” swoich umiejętności tubylcy $\mathrm{z}$ Wysp Trobrianda, których fotografował Bronisław Malinowski? A mimo to fotografiom tym nie można zarzucić nieautentyczności. Wszak $\mathrm{z}$ antropologicznego punktu widzenia autentyczne jest to, co ludzie uważają za autentyczne i to, jak definiują autentyczność. 
Listę dobrych praktyk można oczywiście jeszcze rozwinąć, ale na potrzeby tego typu badań stosowanie reguł przynajmniej w wyżej zakrojonych ramach wystarczy, choć pozostawiamy sobie furtkę do rewizji naszych metod i poszerzenia pola refleksyjności w badaniach z zastosowaniem fotografii, zwłaszcza w sytuacji, kiedy łączymy różne metody badań jakościowych. Badacz w terenie musi jednak wykazać się bezwzględnym poszanowaniem informatorów i choć brzmi to zarozumiale, to jednak warto być gotowym na to, że jeśli żadne z powyższych reguł nie zbudują nici porozumienia $\mathrm{z}$ respondentem, to korzystamy $\mathrm{z}$ anegdoty o słowach wypowiedzianych przez aktora komediowego Groucho Marxa. Miał on ponoć powiedzieć tak: „Nie podobają ci się moje poglądy? W porządku, mam też inne". Wprowadzenie w badanie nuty poczucia humory zazwyczaj zdaje egzamin, jako ostatnia deska ratunku, wówczas pozostaje nam już cała gama metod z zakresu "metodologicznej improwizacji”, której bym nie lekceważył, przede wszystkim jako źródła inspiracji badań w terenie. Jak bowiem zauważa Krzysztof Konecki, „eksperymentowanie z fotografiami w trakcie badań i analiz danych jakościowych może pomóc nam interpretować zjawiska, docierać do ich znaczeń" (Konecki 2019: 38). Jako przykład przytoczę doświadczenie z rozdaniem dzieciom ze szkół wiejskich w Borach Tucholskich jednorazowych aparatów fotograficznych uzbrojonych jedynie w 24-klatkową kliszę. Z 20 aparatów 5 zaginęło $\mathrm{w}$ akcji, 3 zostały rozebrane $\mathrm{z}$ ciekawości, a z pozostałych, które do mnie wróciły, udało się wywołać jedynie kilkadziesiąt odbitek, z których prawie wszystkie przedstawiały linie papilarne autora fotografii. Innymi słowy, nie wyszło, ale warto było spróbować. Zawiodło przede wszystkim zaufanie do kompetencji młodych ludzi, którzy doskonale instalują dziś aplikacje w smartfonach, ale niekoniecznie poradzą sobie $\mathrm{z}$ analogowym aparatem fotograficznym. Z drugiej strony wystarczyło zrobić proste szkolenie, jak w projekcie Through Navajo Eyes, gdzie zaangażowani $\mathrm{w}$ badanie Indianie też musieli się najpierw nauczyć obsługiwać kamery.

Mimo że fotografia dokumentalistyczna jest już mocno ugruntowana $\mathrm{w}$ naukach społecznych, pozwalając czytelnikowi wejść głębiej w proces poznawczy, poznać kontekst wychodzący poza kadr obiektywu, niemalże uczestniczyć w wydarzeniach społecznych i historycznych, to nadal jej obecność jest skromna. Tymczasem nie tylko pomaga w odkryciu prawdziwego znaczenia fotografii, ale bez względu na to, czy jest to portret, czy pejzaż, jest czymś więcej niż formą artystyczną, jest częścią narracji. Nie dociekam, dlaczego w takich książkach jak Poniemieckie Karoliny Kuszyk (2019), Topografia pamięci Martina Pollacka (2017), Umierajacy Europejczycy Karla-Markusa Gaußa (2015) czy o wymownym tytule Wędrowny Zakład Fotograficzny Agnieszki Pajączkowskiej (2019) jest tak niewiele fotografii. We wszystkich wymienionych wyżej tytułach na 1314 stronach jest zaledwie (nie licząc okładki) 50 fotografii, w tym wiele zdjęć archiwalnych ze zbiorów respondentów. Nie rozstrzygam tej kwestii także z powodu faktu, że nie są to książki socjologiczne czy etnograficzne sensu stricto, choć pisane z socjologiczną intuicją. Z własnej praktyki wnioskuję, że fotografia w naukach społecznych, jeśli jest autentyczna, nie zniekształca obrazu i rzeczywistości, nie przetwarza jej, dając widzom i czytelnikom obraz przeniknięty fałszywą inscenizacją, nawet jeśli z uwagi na sposób kadrowania czy wąskie tło pozostawia widzom margines interpretacji. To nawet dobrze. Jak trafnie zauważa historyk sztuki Max Kozloff, autor przedmowy do lekcji czytania fotografii mistrza Iana Jefffreya, „wizualne fakty, których dostarcza fotografia, same z siebie przekazują rzeczywistość czasów, w których zostały wy- 
konane. Zdjęcia jako zakomponowane i zestawione odzwierciedlają narracyjne pragnienie swoich czasów" (Jeffrey 2014: 7).

Stąd też nieustannie ćwicząc się w uważności podczas badań jakościowych, pamiętajmy za Maxem Kozloffem: „docenienie, że zwyczajna nakrętka i śruba mogą przeobrazić się w nieprawdopodobną opowieść, czy nawet mit, oznacza zbliżenie się do istoty fotografii" (Jeffrey 2014: 7). Mariaż fotografii z socjologią czyni poznanie świata społecznego pełniejszym, choć nadal tylko w przybliżeniu pomagającym wyjaśnić, dlaczego świat wygląda tak, jak wygląda. Jak zauważa Douglas Harper, przełomowym artykułem otwierającym niejako nową drogę dla socjologii i fotografii w analizie krytycznej społeczeństwa był tekst Howarda S. Beckera (1974), w którym autor zasugerował, że socjologia wizualna pracuje z takim samym zaangażowaniem i na takim samym poziomie umiejętności jak fotografowie dokumentaliści. Becker stawia socjologom jednak bardzo wysoko poprzeczkę, której wysokość mierzona jest umiejętnością łączenia praktyki fotograficznej z socjologicznymi ideami, metodami i założeniami. I jak dodaje, "chociaż wielu z nas próbowało sprostać temu ideałowi, niewielu, jeśli w ogóle, to osiągnęło" (Harper 2016: 240-241). Przyjęcie perspektywy, jaką oferuje reportaż dialogiczny, niesie ze sobą bez wątpienia obietnicę zanurzenia się $\mathrm{w}$ nieskończonym kalejdoskopie obrazów. Od nas badaczy jednak zależy, jak z tej możliwości skorzystamy.

\section{Zakończenie}

Opisując funkcje fotografii w badaniach socjologicznych, Piotr Sztompka zadaje pytanie, „co zyskuje socjolog, używając aparatu fotograficznego lub włączając zdjęcia fotograficzne do swojej bazy źródłowej" (Sztompka 2005: 71). Wymienia więc i opisuje: funkcje stymulowania uwagi i wyobraźni; funkcję inspiracji heurystycznej; funkcję rejestracji, dokumentacji, opisowej inwentaryzacji faktów wizualnych; funkcję pretekstu dla wywiadu fotograficznego lub dyskusji w grupie zogniskowanej; funkcję dostarczania materiału empirycznego dla pojęć, kategorii i prawidłowości socjologicznych oraz funkcję wykraczającą poza dziedzinę socjologii, czyli zastosowanie fotografii w celach praktycznych - ideologicznych, krytyki społecznej, protestu i tym podobnych (zob. Sztompka 2005: 70-72). Spośród wszystkich wymienionych najbliższa jest mi funkcja stymulowania uwagi i wyobraźni. Proszę sobie wyobrazić ten sam tekst, ale bez fotografii. Tymczasem tekst często potrzebuje ilustracji, a ilustracja opisu - niwelując przez to zagrożenie nadinterpretacji lub fałszywych wniosków. Do tej pory najważniejszym medium przekazu wizualnego była wystawa, album, fotograficzna monografia i oczywiście fotografia prasowa. Dziś szala przechyla się w kierunku obrazów wytwarzanych przez społeczeństwo, czyli zdjęć i filmów upowszechnianych przede wszystkim $\mathrm{w}$ mediach społecznościowych i na kanałach typu YouTube. Także zmieniły się narzędzia rejestracji obrazu z kamery i aparatu na telefon komórkowy. Gdzieś jednak pomiędzy nostalgią czarno-białego pozytywu a cyfrowym zapisem nadal jest miejsce dla fotografii traktowanej jak sztuka i fotografii jako narzędzia badań. Obraz wciąż stanowi niezwykle ważny nośnik informacji nie tylko o społeczeństwie, ale i dla społeczeństwa, wszak, jak pisze Susan Sontag: „rzeczywistość zawsze interpretowano za pomocą obrazów” (Sontag 2012: 387). Stąd też rodzą się pytania do dalszych badań i dociekań, między innymi o to, jak zmieniła się fotografia i czy wciąż obraz ma taką samą moc oddziaływania na społeczeństwo, oraz o to, jakie są możliwości i ograniczenia metod wizualnych $\mathrm{w}$ pracy nad odkrywaniem różnych aspektów życia społecznego? Pozostaje też otwarte pytanie, jak wykorzystać fakt, że jesteśmy 
pierwszym pokoleniem, które może wspominać (na taką skalę) swoich przodków uwiecznionych na fotografii, i pokoleniem, które miesięcznie (tylko w Polsce) wykonuje ponad 2 mld zdjęć. Czy w tej sytuacji, jak piszą Krzysztof Konecki i Anna Kacperczyk, „,możemy zrozumieć więcej, gdy zobaczymy więcej” (Ko-

\section{Bibliografia}

Babbie Earl (2007) Badania społeczne w praktyce. Przełożyli Agnieszka Kłoskowska-Dudzińska i in. Warszawa: Wydawnictwo Naukowe PWN.

Bang Hyejin i in. (2016) Picture Perfect: How Photographs Influence Emotion, Attention and Selection in Social Media News Posts. Odczyt zaprezentowany w 2016 r. podczas „Annual Conference of the Association for Education in Journalism and Mass Communication", Minneapolis.

Baruchel Sylvain i in. (2006) Photo Elicitation Interview (PEI): Using Photos to Elicit Children's Perspectives. „International Journal of Qualitative Methods", vol. 5, no. 3, s. 1-9. DOI: https://doi. org/10.1177/160940690600500301 (https://journals.sagepub.com/ home/ijq) [dostęp 18.05.2021].

Becker Howard Saul (1974) Photography and Sociology. "Studies in Visual Communication", vol. 1, s. 3-26. (https://repository. upenn.edu/svc/vol1/iss1/3) [dostęp 19.04.2021].

Becker Howard Saul (1995) Visual sociology, documentary photography, and photojournalism: It's (almost) all a matter of context. „Visual Sociology", vol. 10, no. (1-2), s. 5-14.

Becker Howard Saul (2012) Socjologia wizualna, fotografia dokumentalna i fotografia reporterska: prawie wszystko zależy od kontekstu [w:] Małgorzata Boguni-Borowska, Piotr Sztompka, red., Fotospołeczeństwo. Antologia tekstów z socjologii wizualnej. Warszawa: Wydawnictwo ZNAK, s. 761-778.

Bohm David (2003) On Dialogue. Edited by Lee Nichol. London, New York: Taylor \& Francis e-Library. .

Dempsey John V., Tucker Susan A. (1994) Using Photo-Interviewing as a Tool for Research and Evaluation. „Educational Technology", vol. 34, no. 4, s. 55-62. (http://www.jstor.org/stable/44428176) [dostęp 15.09.2021]. necki, Kacperczyk 2020: 17). Ten paradoks nadmiaru obrazu w przestrzeni publicznej jest jednak w swej naturze badawczo pociągający, by podjać wyzwanie odpowiedzi na pytanie: jak selekcjonować, gromadzić i w efekcie czynić badania systematycznymi, skoro danych wizualnych jest dziś taki bezmiar?

Fairey Tiffany, Orton Liz (2019) Photography as Dialogue. „Photography and Culture", vol. 12, no. 3, s. 299-305.

Gagnon Julie (2008) Ces lieux qui m’habitent. Faculté d'aménagement, d'architecture et des arts visuels. Québec: Université Laval.

Gauß Karl-Markus (2015) Umierający Europejczycy. Przełożyła Alicja Rosenau. Wołowiec: Wydawnictwo Czarne.

Harper Douglas (2016) The Development of Visual Sociology: A view from the inside. „Società Mutamento Politica”, vol. 7, no. 14, s. 237-250.

Heng Terence (2016) Visual Methods in the Field. Photography for the Social Sciences. London: Routledge.

Heng Terence (2019) Creating Visual Essays: Narrative and Thematic Approaches [w:] L. Pauwels, D. Mannay, eds., The Sage Handbook of Visual Research Methods. London: Sage, s. 617-628.

Heng Terence (2020) Of Gods, Gifts and Ghosts. London: Routledge.

Jeffrey Ian (2014) Jak czytać fotografię. Lekcje mistrzów fotografii. Przełożył Jakub Jedliński. Kraków: UNIVERSITAS.

Jones Stacy Holman, Adams Tony E., Ellis Carolin (2015) Handbook of Autoethnography. Routledge: Walnut Creek.

Kafar Marcin, Kacperczyk Anna (2020) Autoetnograficzne „zbliżenia" $i$ "oddalenia". O autetnografii w Polsce. Łódź: Wydawnictwo Uniwersytetu Łódzkiego.

Kay Tamara (2011) Building Solidarity with Subjects and Audience in Sociology and Documentary Photography. "Sociological Forum", vol. 26, no. 2, s. 424-430.

Konecki Krzysztof Tomasz (2019) Kreatywność w badaniach jakościowych. Pomiędzy procedurami a intuicją. „Przegląd So- 
cjologii Jakościowej". t. 15, nr 3, s. 30-54. DOI: https://doi. org/10.18778/1733-8069.15.3.03 (http://www.qualitativesociologyreview.org/PL/index_pl.php) [dostęp 17.11.2021].

Konecki Krzysztof Tomasz, Kacperczyk Anna (2020) Wizualizacje życia codziennego w badaniach interakcjonistycznych. Łódź: Wydawnictwo Uniwersytetu Łódzkiego.

Kuszyk Karolina (2019) Poniemieckie. Wołowiec: Wydawnictwo Czarne.

Lévi-Strauss Claude (2020) Mit i znaczenie. Pięć wykładów przygotowanych dla radia przez Claude'a Lévi-Straussa. Przełożyli Monika Eccles, Rafał Wiśniewski. Warszawa: Narodowe Centrum Kultury.

Marcysiak Tomasz (2015) Życie społeczne w gminie Cekcyn. Szkic socjologiczny. Toruń: WSB w Toruniu.

Marcysiak Tomasz (2019a) Kosznajderia - przerwana tożsamość [w:] Anna Brzezińska, Agnieszka Szczepaniak-Koll, Anna Szymoszyn, red., 300 lat Bambrów w Poznaniu. Wkład małych wspólnot migracyjnych $w$ dziedzictwo kulturowe Polski. Poznań: Wydawnictwo Miejskie Posnania, Instytut Archeologii i Etnologii PAN, s. 88-114.

Marcysiak Tomasz (2019b) WODA NAPRZÓD! Szkice z wywiadów autobiograficznych druhów Ochotniczych Straży Pożarnych z gminy wiejskiej Golub-Dobrzyń. Toruń: Wydawnictwo Adam Marszałek.

Marcysiak Tomasz, Pretkiel Ilona, Raszkowska Aneta (2017) Between Sociology and Archaeology - On Advantages of Interdisciplinary Research in Villages of Former Recovered Territories. „Torun Social Science Review", vol. 3, no 2/2017 s. 11-21.

Meron Yaron (2019) Photographic (In)authenticity Making Strange as a Creative Practice Response. „Video Journal of Education and Pedagogy", vol. 4, no. 2, s. 60-81. DOI: 10.1163/23644583-00401018 (https:// videoeducationjournal.springeropen.com/) [dostęp 17.11.2021].

Morris John Godfrey (2007) Zdobyć zdjęcie. Moja historia fotografii prasowej. Przełożył Maciej Świerkocki. Warszawa: Wydawnictwo Cyklady.

Olechnicki Krzysztof (2003) Antropologia obrazu. Warszawa: Oficyna Naukowa.

Pajączkowska Agnieszka (2019) Wędrowny Zakład Fotograficzny. Wołowiec: Wydawnictwo Czarne.

Pollack Martin (2017) Topografia pamięci. Wołowiec: Wydawnictwo Czarne.
Roland Barthes (1999) Camera Lucida: Reflections on Photography. New York: Farrar, Straus \& Giroux Inc.

Rose Gillian (2010) Interpretacja materiałów wizualnych. Krytyczna metodologia badań nad wizualnościa. Przełożyła Ewa Klekot. Warszawa: Wydawnictwo Naukowe PWN.

Rouillé André (2007) Fotografia. Między dokumentem a sztuka wspótczesną. Przełożył Oskar Hedemann. Kraków: TAiWPN UNIVERSITATIS.

Rychliński Stanisław (2001) Lustracje społeczne. Warszawa: Instytut Polityki Społecznej i Oficyna Wydawnicza ASPRA-JR.

Serafinelli Elisa (2017) Analysis of Photo Sharing and Visual Social Relationships. Instagram as Case Study. „Photographies”, vol. 10, no. 1, s. 91-111. DOI: https://doi.org/10.1080/17540763.2016.1258 657 (https://www.tandfonline.com/toc/rpho20/current) [dostęp 11.09.2021].

Sontag Susan (2012) Świat obrazów [w:] Małgorzata Boguni-Borowska, Piotr Sztompka, red., Fotospołeczeństwo. Antologia tekstów z socjologii wizualnej. Warszawa: Wydawnictwo ZNAK, s. 387-404.

Stachowska Iwona (2009) Między dokumentacja a kreacją. Rola ciała w fotografii współczesnej. "Pismo Artystyczne”, Format 57/2009, s. 7-10.

Stanley Nick (1996) Photography and the Politics of Engagement. „Journal of Art \& Design Education”, vol. 15, no. 1, s. 95-100. DOI: 10.1111/j.1476-8070.1996.tb00653.x (https://onlinelibrary. wiley.com/journal/14768070) [dostęp 12.09.2021].

Suchar Charles S. (1997) Grounding Visual Sociology Research in Shooting Scripts. "Qualitative Sociology”, vol. 20, no. 1, s. 33-55.

Szarkowski John (2005) The Photographer's Eye and Stephen Shore. The Nature of Photographs [w:] Ashley la Grange, ed., Basic Critical Theory for Photographers. Linacre House, Jordan Hill, Oxford: Elsevier, s. 15-29.

Sztompka Piotr (2005) Socjologia wizualna. Fotografia jako metoda badawcza. Warszawa: Wydawnictwo PWN.

Sztompka Piotr (2012) Wyobraźnia wizualna i socjologia [w:] Małgorzata Boguni-Borowska, Piotr Sztompka, red., Fotospołeczeństwo. Antologia tekstów z socjologii wizualnej. Warszawa: Wydawnictwo ZNAK, s. 11-41.

Urry John (2007) Spojrzenie turysty. Przełożyła Alicja Szulżycka. Warszawa: Wydawnictwo PWN. 


\section{Cytowanie}

Marcysiak Tomasz (2021) Fotografia socjologiczna - w kierunku reportażu dialogicznego. „Przegląd Socjologii Jakościowej”, t. 17, nr 4, s. 44-66 [dostęp dzień, miesiąc, rok]. Dostępny w Internecie: 〈www.przegladsocjologiijakosciowej.org〉. DOI: https://doi. org/10.18778/1733-8069.17.4.03

\section{Sociological Photography: Toward Dialogical Reportage}

Abstract: Almost 10 years of cooperation with a photographer who accompanies me in field research prompts me to share my reflections and methodological comments resulting from the experience of building relationships between a researcher, an informant (informants), and a photographer. Following Piotr Sztompka, I would call this experience the process of shaping the sociological visual imagination. In general, dialogic reportage is about experiencing the world of others and about learning to discover another person as he/she sees himself/herself in the surrounding reality. In the article, I discuss the issues of dialog in visual research, the principles of good practice in sociological photography, and the idea of dialog reportage, illustrating the text with photographs from my own field research carried out as part of projects such as: 'The identity of the post-immigrant community based on the example of Kosznajderia,' 'Everyday life of the inhabitants of the Cekcyn commune in the Tuchola Forest,' 'The impact of archaeological research on the integration of local communities under the project 1000 years of Upper Lusatia,' and 'Biographical sketches of the companions of the Volunteer Fire Brigades in the Golub-Dobrzyń commune.' The author of all the photos is Dariusz Bareya, an artist photographer from Bydgoszcz.

Keywords: dialog reportage, photography, photojournalism, visual sociology, documentary photography, visual imagination 